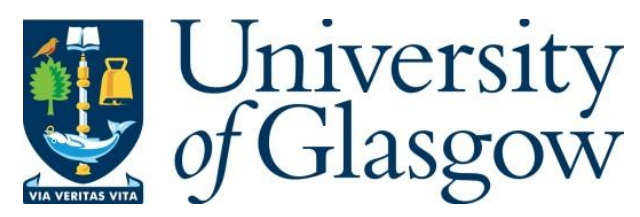

Conradie, J., Conradie, M.M., Tawfiq, K.M., Coles, S.J., Tizzard, G.J., Wilson, C. and Potgieter, J.H. (2018) Jahn-Teller distortion in 2-pyridyl-(1,2,3)-triazole-containing copper(ii) compounds. New Journal of Chemistry, 42(19), pp. 16335-16345.

There may be differences between this version and the published version. You are advised to consult the publisher's version if you wish to cite from it.

http://eprints.gla.ac.uk/170433/

Deposited on: 11 March 2020

Enlighten - Research publications by members of the University of Glasgow http://eprints.gla.ac.uk 


\title{
Jahn-Teller distortion in 2-pyridyl-(1,2,3)-triazole-containing copper(II) compounds
}

J. Conradie ${ }^{1 *}$, M.M. Conradie ${ }^{1}$, K.M. Tawfiq ${ }^{2,3}$, M.J. Al-Jeboori ${ }^{3}$, S.J. Coles ${ }^{4}$, C. Wilson ${ }^{5}$ and J.H. Potgieter $^{2,6^{*}}$

1. Department of Chemistry, University of the Free State, P.O. Box 339, Bloemfontein, 9300, South Africa

2. Division of Chemistry and Environmental Science, Manchester Metropolitan University, Manchester, M1 5GD, England

3. Department of Chemistry, College of Education for Pure Science (Ibn Al-Haitham), University of Baghdad, Baghdad, Iraq

4. EPSRC National Crystallography Service, Chemistry, University of Southampton, Southampton, SO17 1BJ, England

5. School of Chemistry, University of Glasgow, Joseph Black Building. University Avenue, Glasgow, G12 8QQ, Scotland

6. School of Chemical and Metallurgical Engineering, University of the Witwatersrand, Private Bag X3, Wits, 2050, South Africa

*Contact author details:

Name: Jeanet Conradie

Tel: $+27-51-4012194$

Fax: $+27-51-4017295$

e-mail: conradj@ufs.ac.za

\begin{abstract}
The syntheses, characterization and experimental solid state X-ray structures of five low-spin paramagnetic 2-pyridyl-(1,2,3)-triazole-copper compounds, $\left[\mathrm{Cu}\left(\mathrm{L}^{\mathrm{n}}\right)_{2} \mathrm{Cl}_{2}\right]$, are presented in this study, for the following five $\mathrm{L}^{\mathrm{n}}$ ligands: $\mathrm{L}^{2}=2-\left(1-\left(\mathrm{p}\right.\right.$-tolyl)-1H-1,2,3-triazol-4-yl)pyridine), $\mathrm{L}^{6}=2-(1-(4-$ chlorophenyl)-1H-1,2,3-triazol-4-yl)pyridine), $\quad \mathrm{L}^{7} \quad=\quad 4-(4-($ pyridin-2-yl)-1H-1,2,3-triazol-4yl)benzonitril), $\quad \mathrm{L}^{8}=$ 2-(1-phenyl-1H-1,2,3-triazol-4-yl)pyridine) and $\quad \mathrm{L}^{9}=$ 2-(1-(4(trifluoromethyl)phenyl)-1H-1,2,3-triazol-4-yl)pyridine). These five $\left[\mathrm{Cu}\left(\mathrm{L}^{\mathrm{n}}\right)_{2} \mathrm{Cl}_{2}\right]$ complexes each contain two bidentate 2-pyridyl-(1,2,3)-triazole $\left(\mathrm{L}^{\mathrm{n}}\right)$ and two chloride ions as ligands, with the $\mathrm{Cu}$ -
\end{abstract}


$\mathrm{N}$ (pyridine) bonds, $\mathrm{Cu}-\mathrm{N}\left(\right.$ triazole) and $\mathrm{Cu}-\mathrm{Cl}$ bonds trans to each other. All five $\left[\mathrm{Cu}\left(\mathrm{L}^{\mathrm{n}}\right)_{2} \mathrm{Cl}_{2}\right]$ compounds display Jahn-Teller distortion: either compression Jahn-Teller distortion along opposite $\mathrm{Cu}-\mathrm{N}$ (pyridine) bonds, or elongation Jahn-Teller distortion along opposite $\mathrm{Cu}-\mathrm{Cl}$ bonds, as indicated by their obtained solid state crystal structures. Quantum chemistry calculations, using density functional theory, indicated however that Jahn-Teller distortion is in fact possible along any two opposite bonds in these octahedral compounds, i.e. either along the opposite $\mathrm{Cu}-\mathrm{N}$ (pyridine) bonds or along the opposite $\mathrm{Cu}-\mathrm{Cl}$ bonds or the opposite $\mathrm{Cu}-\mathrm{N}($ triazole) bonds.

\section{Keywords}

copper(II); pyridyl-triazole; Jahn-Teller; DFT

\section{TOC graphics and text}

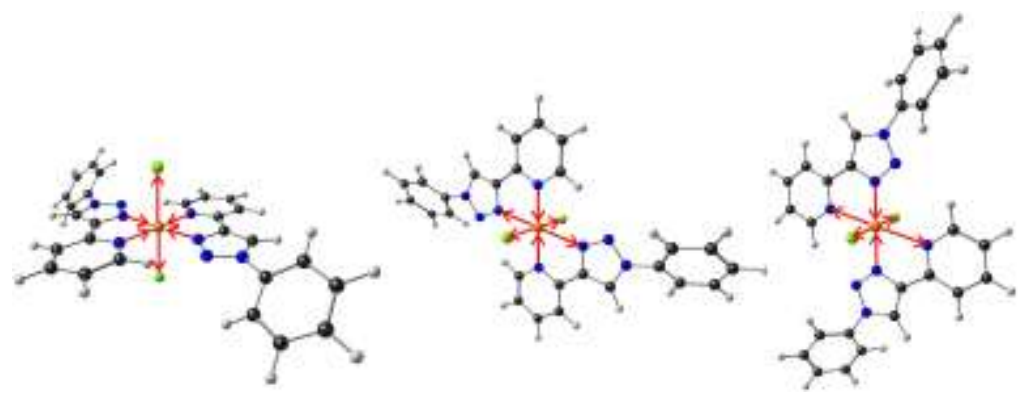

Octahedral copper(II) compounds, containing two 2-pyridyl-(1,2,3)-triazole ligands as well as two $\mathrm{Cl}$ ions, exhibit either compression or elongation Jahn-Teller distortion.

\section{Highlights}

Crystal structures with compression Jahn-Teller distortion

Crystal structures with elongation Jahn-Teller distortion

DFT calculations identify three different types of Jahn-Teller distortion per compound

\section{Introduction}

The Jahn-Teller effect occurs in non-linear systems which contain a degenerate energy state, since a degenerate energy state cannot be stable [1]. Consequently, the Jahn-Teller effect leads to splitting of the degenerate energy states in such a way that the energy of the system is lowered, thus strongly affecting the electron distribution within a material or molecule [2]. The Jahn-Teller effect also often 
has an influence on the arrangement of atoms in a molecule, since the splitting of the degenerate energy states in molecules and ions, which are associated with certain electron configurations, leads to a geometrical distortion. The two main types of geometrical distortions observed for Jahn-Teller active octahedral molecules, are either elongation Jahn-Teller distortion (elongation of the two opposite metal-ligand bonds along the $z$-axis, relative to the four bonds in the $x y$-plane), or compression Jahn-Teller distortion (compression of the two opposite metal-ligand bonds along the $z$ axis, relative to the four bonds in the $x y$-plane). Octahedral $d^{9}$ copper(II) complexes are well known to be Jahn-Teller active, due to the unpaired electron in the $e_{\mathrm{g}}$ level of the octahedral $\mathrm{Cu}$ (II) complexes [2]. Theoretically, it is not possible to predict the type of distortion that will occur with the splitting of degeneracy $e_{\mathrm{g}}$ levels. However, Jahn-Teller distortions for $\mathrm{Cu}$ (II) complexes (with 3 electrons in the $e_{\mathrm{g}}$ level) mostly result in complexes with elongation of the $\mathrm{Cu}$-ligand bonds along the $\mathrm{z}$-axis $[2,3]$, e.g. the hexaaquacopper(II) complex ion, $\left[\mathrm{Cu}\left(\mathrm{OH}_{2}\right)_{6}\right]^{2+}[4]$.

We recently reported on the synthesis of a series of differently substituted 2-(1-phenyl-1H-1,2,3triazol-4-yl)pyridine ligands [5], as well as on the ability of these ligands to coordinate to various first row transition metals, such as manganese, iron, cobalt, nickel, copper and zinc [6,7]. In this study we present the syntheses, characterization and structures of five copper(II) compounds, coordinated to differently substituted 1,2,3-triazole chromophores; namely five $\left[\mathrm{Cu}\left(\mathrm{L}^{\mathrm{n}}\right)_{2} \mathrm{Cl}_{2}\right]$ complexes with the following ligands: $\mathrm{L}^{2}=2$-(1-(p-tolyl)-1H-1,2,3-triazol-4-yl)pyridine), $\mathrm{L}^{6}=2$-(1-(4-chlorophenyl)1H-1,2,3-triazol-4-yl)pyridine), $\mathrm{L}^{7}=$ of 4-(4-(pyridin-2-yl)-1H-1,2,3-triazol-4-yl)benzonitril), $\mathrm{L}^{8}=$ 2-(1-phenyl-1H-1,2,3-triazol-4-yl)pyridine) and $\mathrm{L}^{9}=$ 2-(1-(4-(trifluoromethyl)phenyl)-1H-1,2,3triazol-4-yl)pyridine; see Figure 1. Special emphasis will be given to the Jahn-Teller distortions observed in the solid state structures of these $\mathrm{Cu}(\mathrm{II})$ complexes.

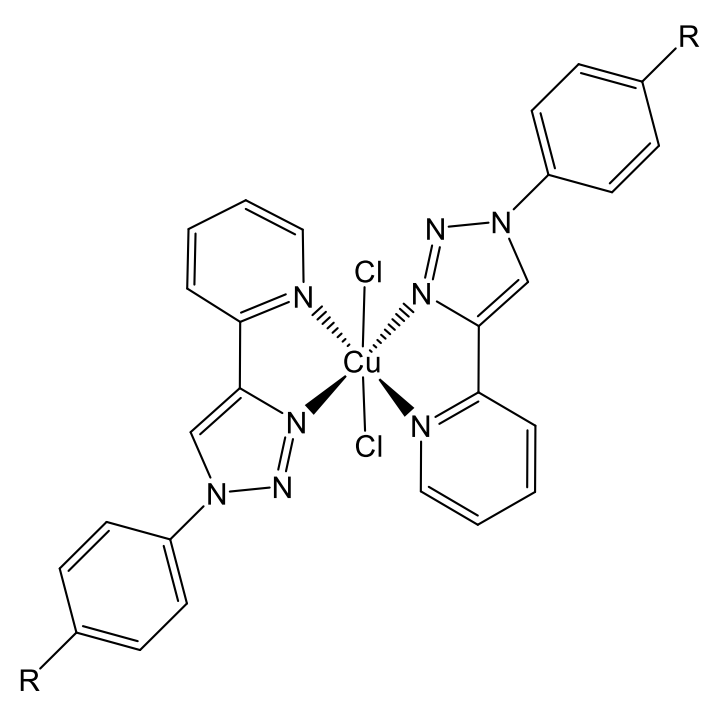

Figure 1: Structure of the 2-pyridyl-(1,2,3)-triazole-copper compounds $(2,6-9)$, where the substituents vary for the $L^{n}$ ligands, namely $R=\mathrm{CH}_{3}\left(\mathrm{~L}^{2}\right), \mathrm{Cl}\left(\mathrm{L}^{6}\right), \mathrm{CN}\left(\mathrm{L}^{7}\right), \mathrm{H}\left(\mathrm{L}^{8}\right)$ and $\mathrm{CF}_{3}\left(\mathrm{~L}^{9}\right)$. 


\section{Methods and Materials}

\subsection{Synthesis of the 2-pyridyl-(1,2,3)-triazole ligands $\left(L^{2}, L^{6}-L^{9}\right)$}

The five (1,2,3-triazol-4-yl)pyridine free ligands $\left(\mathrm{L}^{2}, \mathrm{~L}^{6}-\mathrm{L}^{9}\right)$ were synthesized according to published methods $[8,9,10,11,12]$. The reaction involves the copper(I)-catalysed azide alkyne cycloaddition ( $\mathrm{CuAAC}$ ) reaction between 2-ethynylpyridine and 1-azido-4-R-benzene, where the substituent $\mathrm{R}$ varies for each ligand, namely: $\mathrm{R}=\mathrm{CH}_{3}$ (for $\mathrm{L}^{2}=2$-(1-(p-tolyl)-1H-1,2,3-triazol-4yl)pyridine), $\mathrm{R}=\mathrm{Cl}$ (for $\mathrm{L}^{6}=2$-(1-(4-chlorophenyl)-1H-1,2,3-triazol-4-yl)pyridine), $\mathrm{R}=\mathrm{CN}$ (for $\mathrm{L}^{7}$ $=$ of 4-(4-(pyridin-2-yl)-1H-1,2,3-triazol-4-yl)benzonitril), $\mathrm{R}=\mathrm{H}$ (for $\mathrm{L}^{8}=2$-(1-phenyl-1H-1,2,3triazol-4-yl)pyridine) and $\mathrm{R}=\mathrm{CF}_{3}$ (for $\mathrm{L}^{9}=2$-(1-(4-(trifluoromethyl)phenyl)-1H-1,2,3-triazol-4yl)pyridine). Characterization data of these five ligands is provided in the Supplementary material. For X-ray diffraction analyses of the ligands, see reference [8].

\subsection{Synthesis of the 2-pyridyl-(1,2,3)-triazole-copper compounds, $\left[\mathrm{Cu}\left(\mathrm{L}^{n}\right)_{2} \mathrm{Cl}_{2}\right](2,6-9)$}

The five $\left[\mathrm{Cu}\left(\mathrm{L}^{\mathrm{n}}\right)_{2} \mathrm{Cl}_{2}\right]$ complexes were prepared by dissolving a small amount (ca. $\left.0.3 \mathrm{mmol}\right)$ of anhydrous $\mathrm{CuCl}_{2}$ in $10 \mathrm{ml} \mathrm{CH} \mathrm{CH}_{3} \mathrm{OH}$. A solution of 2 equiv of the respective ligand $\mathrm{L}^{\mathrm{n}}\left(\mathrm{L}^{2}, \mathrm{~L}^{6}-\mathrm{L}^{9}\right)$ in $10 \mathrm{ml} \mathrm{CH} \mathrm{Cl}_{2}$, was added dropwise to the $\mathrm{CuCl}_{2}$ solution and stirred for 8-10 hours at room temperature. The corresponding product $(2,6-9)$ precipitated and was isolated from the solution, by firstly reducing the volume by half under vacuum distillation, and then filtering and washing the precipitate (twice with cold methanol, followed by diethyl ether).

\subsubsection{Dichloro(bis $\left\{2-\left[1-(4-m e t h y l p h e n y l)-1 H-1,2,3-\right.\right.$ triazol-4-yl- $\left.\kappa \mathrm{N}^{3}\right]$ pyridine- $\left.\left.\kappa \mathrm{N}\right\}\right) \operatorname{copper(II)}$} (with ligand $\mathrm{L}^{2}$, where $\mathrm{R}=\mathrm{CH}_{3}$ ) [7]

The preparation of $\left[\mathrm{Cu}\left(\mathrm{L}^{2}\right)_{2} \mathrm{Cl}_{2}\right]$ was conducted according to the general procedure described above: $0.062 \mathrm{~g}(0.46 \mathrm{mmol})$ anhydrous $\mathrm{CuCl}_{2}$ and $0.21 \mathrm{~g}(0.92 \mathrm{mmol})$ of ligand $\mathrm{L}^{2}$ were used, in ratio 1:2. The isolated precipitate produced complex 2 (0.24 g, $0.39 \mathrm{mmol}$, yield 91\%); Colour: green, mp. 274-276 ${ }^{\circ} \mathrm{C}$. IR: $\bar{v}\left(\mathrm{~cm}^{-1}\right): 3068,3058,3025,1606,1594,1575,1516,1477,1449,1267,1250,1063$, 1042, 1029, 862, 817, 779, 754, 716. UV/VIS (DMSO) $\lambda_{\max }$ : The $\mathrm{Cu}$ (II) compound showed absorption bands at $257 \mathrm{~nm}, \varepsilon_{\max }=52222 \mathrm{dm}^{3} \mathrm{~mol}^{-1} \mathrm{~cm}^{-1}, 286 \mathrm{~nm}, \varepsilon_{\max }=35556 \mathrm{dm}^{3} \mathrm{~mol}^{-1} \mathrm{~cm}^{-1}$ and $908 \mathrm{~nm}, \varepsilon_{\max }=85 \mathrm{dm}^{3} \mathrm{~mol}^{-1} \mathrm{~cm}^{-1}$. Compound 2 with ligand $\mathrm{L}^{2}$ showed a value of $\mu_{\mathrm{eff}}=1.70$ B.M. HRMS (P+NSI) $\left(\mathrm{CH}_{3} \mathrm{OH}\right) /\left(\mathrm{NH}_{4} \mathrm{OAC}\right)$ with the highest molecular weight ion peak matching, was observed at $m / z=594.1547(45 \%)$ and is attributed to $\left[\left(\mathrm{Cu}\left(\mathrm{L}^{2}\right)_{2}\right)^{+}+\left(\mathrm{CH}_{3} \mathrm{COO}^{-}\right)\right]^{+}$. The calculated value for $\left[\left[\mathrm{C}_{28} \mathrm{H}_{24} \mathrm{CuN}_{8}\right]^{+}+\left(\mathrm{CH}_{3} \mathrm{COO}^{-}\right)\right]^{+}$is 594.1540 . A good single crystal for $\mathrm{X}$-ray structural 
analysis was obtained by slow evaporation of a hot $\mathrm{CH}_{3} \mathrm{OH}$ solution of the compound. Conductivity: $\Lambda_{\mathrm{M}}(\mathrm{DMSO})=31 \Omega^{-1} \mathrm{~cm}^{2} \mathrm{~mol}^{-1}$.

\subsubsection{Dichloro(bis $\left\{2-\left[1-(4-c h l o r o p h e n y l)-1 \mathrm{H}-1,2,3-\right.\right.$ triazol-4-yl- $\left.\mathrm{kN} \mathrm{N}^{3}\right]$ pyridine- $\left.\left.\mathrm{\kappa N}\right\}\right) \operatorname{copper}(\mathrm{II})$} (with ligand $\mathrm{L}^{6}$, where $\mathrm{R}=\mathrm{Cl}$ )

The preparation of $\left[\mathrm{Cu}\left(\mathrm{L}^{6}\right)_{2} \mathrm{Cl}_{2}\right]$ was conducted according to the general procedure described above: $0.03 \mathrm{~g}(0.24 \mathrm{mmol})$ anhydrous $\mathrm{CuCl}_{2}$ and $0.13 \mathrm{~g}(0.50 \mathrm{mmol})$ of ligand $\mathrm{L}^{6}$ were used, in ratio $1: 2$. The isolated precipitate produced complex $6(0.135 \mathrm{~g}, 0.20 \mathrm{mmol}$, yield 89\%); Colour: green, mp. 274$276^{\circ} \mathrm{C}$. IR: $\bar{v}\left(\mathrm{~cm}^{-1}\right): 3068,3043,3022,1607,1572,1501,1474,1450,1407,1280,1250,1157,1092$, 1064, 1040, 1027, 1013, 998, 861, 824, 779, 781, 711. UV/VIS (DMSO) $\lambda_{\max }$ : The Cu(II) compound showed absorption bands at $252 \mathrm{~nm}, \varepsilon_{\max }=34583 \mathrm{dm}^{3} \mathrm{~mol}^{-1} \mathrm{~cm}^{-1} ; 260 \mathrm{~nm}, \varepsilon_{\max }=41250 \mathrm{dm}^{3} \mathrm{~mol}^{-1} \mathrm{~cm}^{-}$ 1; $288 \mathrm{~nm}, \varepsilon_{\max }=44167 \mathrm{dm}^{3} \mathrm{~mol}^{-1} \mathrm{~cm}^{-1}$; and $876 \mathrm{~nm}, \varepsilon_{\max }=71 \mathrm{dm}^{3} \mathrm{~mol}^{-1} \mathrm{~cm}^{-1}$. Compound 6 with ligand $\mathrm{L}^{6}$ showed a value of $\mu_{\mathrm{eff}}=1.70$ B.M. HRMS TOF $(\mathrm{ESI}+)$ (water : acetonitrile $=1: 3$ ) with the highest molecular weight ion peak matching, was observed at $\mathrm{m} / z=610.0009(100 \%)$ which corresponds to $\left[\left[\mathrm{Cu}\left(\mathrm{L}^{6}\right)_{2} \mathrm{Cl}_{2}\right]-\mathrm{Cl}\right]^{+}$. The calculated value for $\left[\mathrm{C}_{26} \mathrm{H}_{18} \mathrm{~N}_{8} \mathrm{CuCl}_{3}\right]^{+}$is 610.0016 . A good single crystal for X-ray structural analysis was obtained by slow evaporation of a hot solution (methanol : acetonitrile $=1: 1$ ) of the compound. Conductivity: $\Lambda_{\mathrm{M}}(\mathrm{DMSO})=24 \Omega^{-1} \mathrm{~cm}^{2} \mathrm{~mol}^{-1}$.

2.2.3 Dichloro(bis $\left\{4-\left[4-\left(\right.\right.\right.$ pyridin-2-yl-kN)- $1 H-1,2,3-$ triazol-1-yl- $\left.\mathrm{KN}^{3}\right]$ benzonitrile $\left.\left.\}\right)\right] \quad$ copper(II) (with ligand $\mathrm{L}^{7}$, where $\mathrm{R}=\mathrm{CN}$ )

The preparation of $\left[\mathrm{Cu}\left(\mathrm{L}^{7}\right)_{2} \mathrm{Cl}_{2}\right]$ was conducted according to the general procedure described above: $0.036 \mathrm{~g}(0.26 \mathrm{mmol})$ anhydrous $\mathrm{CuCl}_{2}$ and $0.13 \mathrm{~g}(0.53 \mathrm{mmol})$ of ligand $\mathrm{L}^{7}$ were used, in ratio 1:2. The isolated precipitate produced complex 7 (0.136 g, $0.21 \mathrm{mmol}$, yield 90\%); Colour: green, mp. 292-294 ${ }^{\circ} \mathrm{C}$. IR: $\bar{v}\left(\mathrm{~cm}^{-1}\right): 3077,3038,3004,2232,1634,1616,1601,1594,1579,1516,1475,1449$, 1456, 1411, 1371, 1288, 1279, 1161, 1149, 1061, 1010, 978, 858, 826, 797, 720. UV/VIS (DMSO) $\lambda_{\text {max }}$ : The $\mathrm{Cu}(\mathrm{II})$ compound showed absorption bands at $258 \mathrm{~nm}, \varepsilon_{\max }=57278 \mathrm{dm}^{3} \mathrm{~mol}^{-1} \mathrm{~cm}^{-1}, 299 \mathrm{~nm}$, $\varepsilon_{\max }=48636 \mathrm{dm}^{3} \mathrm{~mol}^{-1} \mathrm{~cm}^{-1}$, and $922 \mathrm{~nm}, \varepsilon_{\max }=121 \mathrm{dm}^{3} \mathrm{~mol}^{-1} \mathrm{~cm}^{-1}$. Compound 7 with ligand $\mathrm{L}^{7}$ showed a value of $\mu_{\text {eff }}=1.64$ B.M. HRMS TOF $($ ESI +$)$ (water $:$ acetonitrile $\left.=1: 3\right)$ with the highest molecular weight ion peak matching, was observed at $\mathrm{m} / \mathrm{z}=592.0712(75 \%)$ and is related to $\left[\left[\mathrm{Cu}\left(\mathrm{L}^{7}\right)_{2} \mathrm{Cl}_{2}\right]-\mathrm{Cl}\right]^{+}$. The calculated value for $\left[\mathrm{C}_{28} \mathrm{H}_{18} \mathrm{~N}_{10} \mathrm{ClCu}\right]^{+}$is 592.0700 . A good single crystal for X-ray structural analysis was obtained by slow evaporation of a hot solution (methanol : acetonitrile $=1: 1)$ of the compound. Conductivity: $\Lambda_{\mathrm{M}}(\mathrm{DMSO})=26 \Omega^{-1} \mathrm{~cm}^{2} \mathrm{~mol}^{-1}$. 
2.2.4 Dichloro \{bis[2-(1-phenyl-1H-1,2,3-triazol-4-yl- $\mathrm{NN}^{3}$ )pyridine- $\mathrm{NN}$ ] $\}$ copper(II) (with ligand $\mathrm{L}^{8}$, where $\mathrm{R}=\mathrm{H}$ )

The preparation of $\left[\mathrm{Cu}\left(\mathrm{L}^{8}\right)_{2} \mathrm{Cl}_{2}\right]$ was conducted according to the general procedure described above: $0.055 \mathrm{~g}(0.40 \mathrm{mmol})$ anhydrous $\mathrm{CuCl}_{2}$ and $0.18 \mathrm{~g}(0.81 \mathrm{mmol})$ of ligand $\mathrm{L}^{8}$ were used, in ratio 1:2. The isolated precipitate produced complex 8 (0.22 g, $0.38 \mathrm{mmol}$, yield 93\%); Colour: green, mp. 282-284 ${ }^{\circ}$ C. IR: $\bar{v}\left(\mathrm{~cm}^{-1}\right): 3059,3028,3014,1608,1595,1574,1505,1475,1467,1448,1269,1254$, 1065, 1047, 1028, 1002, 973, 912, 858,783, 757, 733, 685. UV/VIS (DMSO) $\lambda_{\max }$ : The Cu(II) compound showed absorption bands at $258 \mathrm{~nm}, \varepsilon_{\max }=44286 \mathrm{dm}^{3} \mathrm{~mol}^{-1} \mathrm{~cm}^{-1} ; 285 \mathrm{~nm}, \varepsilon_{\max }=31429$ $\mathrm{dm}^{3} \mathrm{~mol}^{-1} \mathrm{~cm}^{-1}$; and $908 \mathrm{~nm}, \varepsilon_{\max }=13 \mathrm{dm}^{3} \mathrm{~mol}^{-1} \mathrm{~cm}^{-1}$. Compound 8 with ligand $\mathrm{L}^{8}$ showed a value of $\mu_{\text {eff }}=1.71$ B.M. HRMS TOF $($ ESI + ) (water : acetonitrile $=1: 3$ ) with the highest molecular weight ion peak matching, was observed at $m / z=542.0817(20 \%)$ and is related to $\left[\left[\mathrm{Cu}\left(\mathrm{L}^{8}\right)_{2} \mathrm{Cl}_{2}\right]-\mathrm{Cl}\right]^{+}$. The calculated value for $\left[\mathrm{C}_{26} \mathrm{H}_{20} \mathrm{~N}_{8} \mathrm{ClCu}\right]^{+}$is 542.0795. A good single crystal for $\mathrm{X}$-ray structural analysis was obtained by slow evaporation of a hot $\mathrm{CH}_{3} \mathrm{OH}$ solution of the compound. Conductivity: $\Lambda_{\mathrm{M}}$ $(\mathrm{DMSO})=26 \Omega^{-1} \mathrm{~cm}^{2} \mathrm{~mol}^{-1}$.

2.2.5 Dichloro[bis(2-\{1-[4-(trifluoromethyl)phenyl]-1H-1,2,3-triazol-4-yl- $\left.\mathrm{kN}^{3}\right\}$ pyridine$\kappa \mathrm{N}$ )] copper(II) (with ligand $\mathrm{L}^{9}$, where $\mathrm{R}=\mathrm{CF}_{3}$ )

The preparation of $\left[\mathrm{Cu}\left(\mathrm{L}^{9}\right)_{2} \mathrm{Cl}_{2}\right]$ was conducted according to the general procedure described above: $0.055 \mathrm{~g}(0.40 \mathrm{mmol})$ anhydrous $\mathrm{CuCl}_{2}$ and $0.23 \mathrm{~g}(0.80 \mathrm{mmol})$ of ligand $\mathrm{L}^{9}$ were used, in ratio 1:2. The isolated precipitate produced complex $9(0.24 \mathrm{~g}, 0.33 \mathrm{mmol}$, yield $82 \%)$; Colour: green, mp. 248 $250^{\circ} \mathrm{C}$. IR: $\bar{v}\left(\mathrm{~cm}^{-1}\right): 3060,3044,3026,1617,1608,1577,1526,1518,1478,1453,1332,1274,1251$, 1065, 1038, 1028, 1015, 865, 844, 782, 757, 732. UV/VIS (DMSO) $\lambda_{\max }$ : The Cu(II) compound showed absorption bands at $258 \mathrm{~nm}, \varepsilon_{\max }=58947 \mathrm{dm}^{3} \mathrm{~mol}^{-1} \mathrm{~cm}^{-1} ; 287 \mathrm{~nm}, \varepsilon_{\max }=47368 \mathrm{dm}^{3} \mathrm{~mol}^{-1} \mathrm{~cm}^{-}$ 1; 496nm, $\varepsilon_{\max }=62 \mathrm{dm}^{3} \mathrm{~mol}^{-1} \mathrm{~cm}^{-1}$; and $888 \mathrm{~nm}, \varepsilon_{\max }=62 \mathrm{dm}^{3} \mathrm{~mol}^{-1} \mathrm{~cm}^{-1}$. Compound 9 with ligand $\mathrm{L}^{9}$ showed a value of $\mu_{\mathrm{eff}}=1.60$ B.M. HRMS (P+NSI) with the highest molecular weight ion peak matching, was observed at $m / z=678.0532(100 \%)$ and is attributed to $\left[\left[\mathrm{Cu}\left(\mathrm{L}^{9}\right)_{2} \mathrm{Cl}_{2}\right]-\mathrm{Cl}\right]^{+}$. The calculated value for $\left[\mathrm{C}_{28} \mathrm{H}_{18} \mathrm{ClF}_{6} \mathrm{~N}_{8} \mathrm{Cu}\right]^{+}$is 678.0538 . A good single crystal for $\mathrm{X}$-ray structural analysis was obtained by slow evaporation of a hot $\mathrm{CH}_{3} \mathrm{OH}$ solution of the compound. Conductivity: $\Lambda_{\mathrm{M}}(\mathrm{DMSO})=28 \Omega^{-1} \mathrm{~cm}^{2} \mathrm{~mol}^{-1}$.

\subsection{Instruments and measurement parameters}

Infrared (ATR-FTIR IR) spectra were recorded, using a smart diamond ATR attachment on a Thermo-Nicolet FT-IR Spectrometer (AVATAR 320), over the range of 4000 to $400 \mathrm{~cm}^{-1}$. UV-Vis spectra were obtained on a PerkinElmer lambda $40 \mathrm{UV} / \mathrm{Vis}$ spectrometer. Mass spectra were 
performed at the EPSRC Mass Spectrometry Service Centre, University of Wales, Swansea and at the University of Sheffield. The instrument used was the 'WATERS LCT premier', the ionization was electrospray (ESI+ and ES-), while the solvent was water/acetonitrile (1:3). Thermofisher LTQ Orbitrap XL was used to analyze volatile molecules in the mass range $\mathrm{m} / \mathrm{z} 50-2000$ or $\mathrm{m} / \mathrm{z} 200-4000$ Daltons. Magnetic susceptibility was measured using a Gouy magnetic susceptibility balance. The gram magnetic susceptibility for a substance was calculated from: $\chi_{g}=\left(C_{b a l}\right)(\ell)\left(R-R_{o}\right) /\left(10^{9}\right)(m)$; where $\ell=$ height of sample in the tube in units of centimeters, $m=$ mass of the sample in units of grams, $\mathrm{R}=$ reading for tube plus sample, $\mathrm{R}_{\mathrm{o}}=$ reading for the empty tube, and $\mathrm{C}_{\mathrm{bal}}=$ balance calibration constant $=1.0$. The molar magnetic susceptibility was subsequently calculated from the gram magnetic susceptibility, using: $\chi_{\mathrm{m}}=\left(\chi_{\mathrm{g}}\right) \mathrm{M}$, where $\mathrm{M}=$ molar mass. The effective magnetic moment for a particular substance was then calculated from the molar magnetic susceptibility [13] by using: $\mu_{\text {eff }}=2.83\left[\left(\chi_{\mathrm{m}}\right)(\mathrm{T})\right]^{1 / 2}(\mathrm{~T}=294 \mathrm{~K})$. These calculated $\mu_{\text {eff }}$ values for the five $\left[\mathrm{Cu}\left(\mathrm{L}^{\mathrm{n}}\right)_{2} \mathrm{Cl}_{2}\right]$ complexes (where $\mathrm{L}^{\mathrm{n}}=\mathrm{L}^{2}, \mathrm{~L}^{6}, \mathrm{~L}^{7}, \mathrm{~L}^{8}$ and $\mathrm{L}^{9}$ ), are given in the experimental characterization data. The molar conductivity measurements of these $\left[\mathrm{Cu}\left(\mathrm{L}^{\mathrm{n}}\right)_{2} \mathrm{Cl}_{2}\right]$ compounds were conducted, using $10^{-3}$ M solutions of these five complexes in DMSO.

\subsection{X-ray diffraction}

Single crystal X-ray diffraction measurements were performed, using a Rigaku SPIDER RAXIS image plate detector, equipped with an enhanced sensitivity (HG) Saturn724+ detector, mounted at the window of an FR-E+ SuperBright molybdenum rotating anode generator, as well as a Rigaku

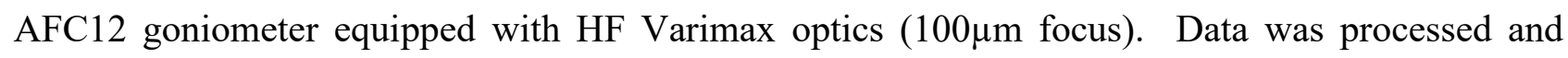
empirical absorption corrections were carried out, using Crystal Clear SM-Expert [14]. The structures were solved by direct methods, using SHELXS-97 within OLEX2 [15]. All refinements on $\mathrm{F}_{\mathrm{o}}^{2}$ by full-matrix least squares refinement, were performed using the SHELXL-97 program package [16]. All non-hydrogen atoms were refined by anisotropic displacement parameters. Hydrogen atoms were added at calculated positions and were included as part of a riding model, with the aromatic bond lengths at $\mathrm{C}-\mathrm{H}$ (aromatic) $0.95 \AA \mathrm{U}_{\mathrm{ISO}}=1.2 \mathrm{U}_{\text {eq }}(\mathrm{C})$; and the methyl bond lengths at $\mathrm{C}-\mathrm{H}$ (methyl) $0.98 \AA \mathrm{U}_{\mathrm{ISO}}=1.5 \mathrm{U}_{\mathrm{eq}}(\mathrm{C})[17]$. Perspective drawings of the molecular structure of compounds, also showing the atom numbering scheme used, are shown in Figure 2 to Figure 6. Crystallographic data is presented in Table 2, with selected geometrical parameters given in Table 3, Table 4 and Table 5. Additional crystallographic data is provided in the Electronic Supplementary Information.

\subsection{Theoretical approach}

Density functional theory (DFT) calculations were performed with the B3LYP functional, as implemented in the Gaussian 09 package [18], using the triple- $\zeta$ basis set $6-311 \mathrm{G}(\mathrm{d}, \mathrm{p})$. Since the compounds of this study are low-spin paramagnetic $\mathrm{d}^{9}$ compounds, all calculations were conducted 
as for a doublet, unrestricted in the gas phase. All structures were confirmed to be true minimum structures by a frequency analysis, i.e. no imaginary frequencies. The input coordinates for the compounds were constructed using Chemcraft [19], as well as from available crystal data. The optimized coordinates of the DFT calculations are provided in the Supporting Information.

\section{Results and discussion}

\subsection{Characterization}

The five 2-pyridyl-(1,2,3)-triazole-copper compounds $(\mathbf{2}, \mathbf{6}-\mathbf{9})$, with the substituents on the respective ligands $\mathrm{L}^{n}$ being $\mathrm{R}=\mathrm{CH}_{3}\left(\mathrm{~L}^{2}\right), \mathrm{Cl}\left(\mathrm{L}^{6}\right), \mathrm{CN}\left(\mathrm{L}^{7}\right), \mathrm{H}\left(\mathrm{L}^{8}\right)$ and $\mathrm{CF}_{3}\left(\mathrm{~L}^{9}\right)$, were synthesized from a 2:1 mole ratio of the respective 2-pyridyl-(1,2,3)-triazole ligand $\left(\mathrm{L}^{\mathrm{n}}\right)$ with $\mathrm{CuCl}_{2}$, see Scheme 1. The five $\left[\mathrm{Cu}\left(\mathrm{L}^{\mathrm{n}}\right)_{2} \mathrm{Cl}_{2}\right]$ complexes of this study are low-spin paramagnetic $\mathrm{d}^{9}$ compounds, which therefore cannot be characterized by NMR. Therefore, a X-ray single-crystal diffraction analysis of each of the five $\left[\mathrm{Cu}\left(\mathrm{L}^{\mathrm{n}}\right)_{2} \mathrm{Cl}_{2}\right]$ compounds is presented in section 3.2. The five compounds were further characterized by FT-IR, MS, UV-VIS, melting points and magnetic moments (see experimental section 2.2). Additionally, computational chemistry calculations (section 3.3) were conducted for complexes 2, 6-9. The experimentally measured magnetic moment values obtained for these compounds with $\mathrm{S}=1 / 2$, were $c a$. 1.7 B.M. (see Table 1). These values are consistent with the presence of one unpaired electron, since $\mu_{\text {eff }}=\sqrt{S(S+1)}=2 \sqrt{\frac{1}{2}\left(\frac{1}{2}+1\right)}=1.73$. The UV-Vis spectra of the five free ligands $L^{2}, L^{6}, L^{7}, L^{8}$ and $L^{9}$, all exhibit intraligand $\pi \rightarrow \pi^{*}, n \rightarrow \pi^{*}$ transitions, between 283 and $288 \mathrm{~nm}$. Upon complexation to copper, at least two of these intraligand transitions were still observed, although slightly shifted from the wavelength position of the free ligand, as well as additional copper $d-d$ transitions, which were observed above $450 \mathrm{~nm}$ (see Table 1).

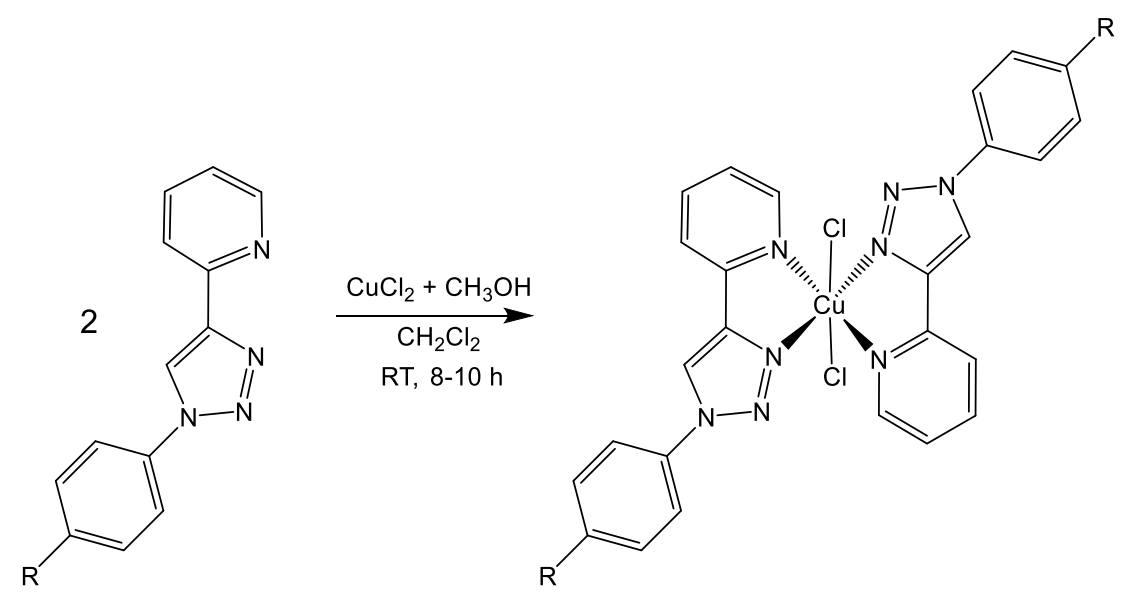


Scheme 1. Synthesis of the five 2-pyridyl-(1,2,3)-triazole-copper compounds $(2,6-9)$, from the respective ligand $\left(L^{n}\right)$ with $\mathrm{CuCl}_{2}$, with the following substituents on the ligands: $R=\mathrm{CH}_{3}\left(\mathrm{~L}^{2}\right), \mathbf{C l}\left(\mathrm{L}^{6}\right), \mathbf{C N}\left(\mathrm{L}^{7}\right), \mathrm{H}\left(\mathrm{L}^{8}\right)$ and $\mathrm{CF}_{3}$ $\left(\mathbf{L}^{9}\right)$ 


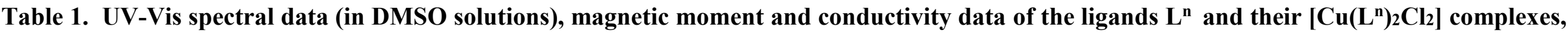
with the substituents on $L^{n}$ as follows: $R=C_{3}$ (for $L^{2}$ ), $C l$ (for $L^{6}$ ), $C N$ (for $L^{7}$ ), $H$ (for $L^{8}$ ) and $C F_{3}\left(\right.$ for $L^{9}$ ).

\begin{tabular}{|c|c|c|c|c|c|c|}
\hline Compound & $\begin{array}{c}\text { Band position } \\
\lambda_{\max }(\mathrm{nm})\end{array}$ & Wave number $\left(\mathrm{cm}^{-1}\right)$ & $\begin{array}{c}\text { Extinction coefficient } \\
\varepsilon_{\max }\left(\mathrm{dm}^{3} \mathrm{~mol}^{-1} \mathrm{~cm}^{-1}\right)\end{array}$ & Assignment & $\mu_{\text {eff }}$ B.M. & $\begin{array}{l}\text { Conductivity } \\
\Lambda_{M}\left(\mathrm{~cm}^{2} \Omega^{-1} \mathrm{~mol}^{-1}\right)\end{array}$ \\
\hline $\mathrm{L}^{2}$ & 283 & 34843 & $17200,\left(4 \times 10^{-5} \mathrm{M}\right)$ & Intraligand $\pi \rightarrow \pi^{*}, \mathrm{n} \rightarrow \pi^{*}$ & & \\
\hline$\left[\mathrm{Cu}\left(\mathrm{L}^{2}\right)_{2} \mathrm{Cl}_{2}\right]$ & $\begin{array}{l}279,284 \\
908\end{array}$ & $\begin{array}{c}35842,35211 \\
11013\end{array}$ & $\begin{array}{c}3507,3603,\left(1 \times 10^{-3} \mathrm{M}\right) \\
85\end{array}$ & $\begin{array}{c}\text { Intraligand } \pi \rightarrow \pi^{*}, \mathrm{n} \rightarrow \pi^{*} \\
{ }^{2} \mathrm{~B}_{1 \mathrm{~g}} \rightarrow{ }^{2} \mathrm{~B}_{2 \mathrm{~g}}\end{array}$ & 1.70 & 26 \\
\hline $\mathrm{L}^{6}$ & 284 & 35211 & $23925,\left(4 \times 10^{-6} \mathrm{M}\right)$ & Intraligand $\pi \rightarrow \pi^{*}, \mathrm{n} \rightarrow \pi^{*}$ & & \\
\hline$\left[\mathrm{Cu}\left(\mathrm{L}^{6}\right)_{2} \mathrm{Cl}_{2}\right]$ & $\begin{array}{c}260,288 \\
876\end{array}$ & $\begin{array}{c}38461,34722 \\
11415\end{array}$ & $\begin{array}{c}41250,44167,\left(2.4 \times 10^{-6} \mathrm{M}\right) \\
68,\left(1 \times 10^{-3} \mathrm{M}\right)\end{array}$ & $\begin{array}{c}\text { Intraligand } \pi \rightarrow \pi^{*}, \mathrm{n} \rightarrow \pi^{*} \\
{ }^{2} \mathrm{~B}_{1 \mathrm{~g}} \rightarrow{ }^{2} \mathrm{E}_{\mathrm{g}}\end{array}$ & 1.70 & 24 \\
\hline $\mathrm{L}^{7}$ & 285 & 34246 & $24375,\left(4 \times 10^{-6} \mathrm{M}\right)$ & Intraligand $\pi \rightarrow \pi^{*}, \mathrm{n} \rightarrow \pi^{*}$ & & \\
\hline$\left[\mathrm{Cu}\left(\mathrm{L}^{7}\right)_{2}\left(\mathrm{Cl}_{2}\right]\right.$ & $\begin{array}{l}258,299 \\
922\end{array}$ & $\begin{array}{c}38759,33444 \\
11261\end{array}$ & $\begin{array}{c}57278,48636,\left(2.2 \times 10^{-3} \mathrm{M}\right) \\
121,\left(1 \times 10^{-3} \mathrm{M}\right)\end{array}$ & $\begin{array}{c}\text { Intraligand } \pi \rightarrow \pi^{*}, \mathrm{n} \rightarrow \pi^{*} \\
{ }^{2} \mathrm{~B}_{1 \mathrm{~g}} \rightarrow{ }^{2} \mathrm{~B}_{\mathrm{g}}\end{array}$ & 1.71 & 26 \\
\hline $\mathrm{L}^{8}$ & 284 & 35211 & $24375,\left(4 \times 10^{-6} \mathrm{M}\right)$ & Intraligand $\pi \rightarrow \pi^{*}, \mathrm{n} \rightarrow \pi^{*}$ & & \\
\hline$\left[\mathrm{Cu}\left(\mathrm{L}^{8}\right)_{2} \mathrm{Cl}_{2}\right]$ & $\begin{array}{l}258,285 \\
908\end{array}$ & $\begin{array}{c}34965,35087 \\
11013\end{array}$ & $\begin{array}{c}44286,31429,\left(2.8 \times 10^{-6} \mathrm{M}\right) \\
13,\left(1 \times 10^{-3} \mathrm{M}\right)\end{array}$ & $\begin{array}{c}\text { Intraligand } \pi \rightarrow \pi^{*}, \mathrm{n} \rightarrow \pi^{*} \\
{ }^{2} \mathrm{~B}_{1 \mathrm{~g}} \rightarrow{ }^{2} \mathrm{~B}_{2 \mathrm{~g}}\end{array}$ & 1.71 & 26 \\
\hline $\mathrm{L}^{9}$ & 288 & 34722 & $14980,\left(8 \times 10^{-6} \mathrm{M}\right)$ & Intraligand $\pi \rightarrow \pi^{*}, \mathrm{n} \rightarrow \pi^{*}$ & & \\
\hline$\left[\mathrm{Cu}\left(\mathrm{L}^{9}\right)_{2} \mathrm{Cl}_{2}\right]$ & $\begin{array}{c}258,287 \\
496 \\
888\end{array}$ & $\begin{array}{c}35971,33557,32573 \\
20161 \\
11261\end{array}$ & $\begin{array}{c}58947,47368,\left(1.9 \times 10^{-3} \mathrm{M}\right) \\
62,\left(1 \times 10^{-3} \mathrm{M}\right) \\
62,\left(1 \times 10^{-3} \mathrm{M}\right)\end{array}$ & $\begin{array}{c}\text { Intraligand } \pi \rightarrow \pi^{*}, \mathrm{n} \rightarrow \pi^{*} \\
{ }^{2} \mathrm{~B}_{1 \mathrm{~g}} \rightarrow{ }^{2} \mathrm{~A}_{2 \mathrm{~g}} \\
{ }^{2} \mathrm{~B}_{1 \mathrm{~g}} \rightarrow{ }^{2} \mathrm{~B}_{2 \mathrm{~g}}\end{array}$ & 1.60 & 28 \\
\hline
\end{tabular}




\subsection{X-ray structures}

Perspective views of the molecular structures, obtained from the five X-ray single-crystal diffraction analyses of the five $\left[\mathrm{Cu}\left(\mathrm{L}^{\mathrm{n}}\right)_{2} \mathrm{Cl}_{2}\right]$ complexes $(\mathbf{2}, \mathbf{6}-\mathbf{9})$ with ligands $\mathrm{L}^{2}, \mathrm{~L}^{6}, \mathrm{~L}^{7}, \mathrm{~L}^{8}$ and $\mathrm{L}^{9}$, are shown in Figure 2 to Figure 6. The structures confirmed that the copper(II) complexes were formed with two bidentate ligands and two chloride ions as a coligands. The single crystals of the compounds $\left[\mathrm{Cu}\left(\mathrm{L}^{2}\right)_{2} \mathrm{Cl}_{2}\right],\left[\mathrm{Cu}\left(\mathrm{L}^{6}\right)_{2} \mathrm{Cl}_{2}\right],\left[\mathrm{Cu}\left(\mathrm{L}^{7}\right)_{2} \mathrm{Cl}_{2}\right],\left[\mathrm{Cu}\left(\mathrm{L}^{8}\right)_{2} \mathrm{Cl}_{2}\right]$ and $\left[\mathrm{Cu}\left(\mathrm{L}^{9}\right)_{2} \mathrm{Cl}_{2}\right]$, were grown by slow evaporation of methanol or methanol/acetonitrile solvents in a ratio of 1:2. Unit cell data collection and structure refinement details are provided in Table 2, while selected bond lengths, bond angles and torsion angles are listed in Table 3, Table 4 and Table 5 respectively. Both the compounds $\left[\mathrm{Cu}\left(\mathrm{L}^{2}\right)_{2} \mathrm{Cl}_{2}\right]$ and $\left[\mathrm{Cu}\left(\mathrm{L}^{8}\right)_{2} \mathrm{Cl}_{2}\right]$ crystallized in the monoclinic space group $\mathrm{P} 21 / \mathrm{c}$. The compounds $\left[\mathrm{Cu}\left(\mathrm{L}^{6}\right)_{2} \mathrm{Cl}_{2}\right]$ and $\left[\mathrm{Cu}\left(\mathrm{L}^{9}\right)_{2} \mathrm{Cl}_{2}\right]$ crystallized in orthorhombic space groups of Pccn and Pca21, respectively. The compound $\left[\mathrm{Cu}\left(\mathrm{L}^{7}\right)_{2} \mathrm{Cl}_{2}\right]$ crystallized in the triclinic space group $\mathrm{P}-1$.

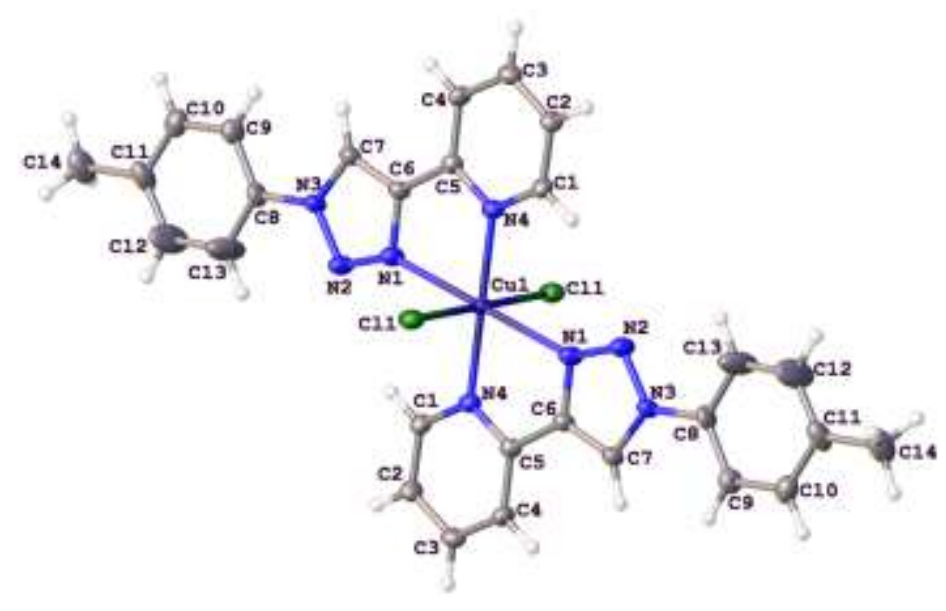

Figure 2. View of complex $\left[\mathrm{Cu}\left(\mathrm{L}^{2}\right)_{2} \mathrm{Cl}_{2}\right]$, showing the atom labelling scheme. The thermal ellipsoids are drawn at a 50\% probability level and $H$ atoms are shown as small spheres of arbitrary size. Group $R=\mathrm{CH}_{3}$ (ligand $\mathrm{L}^{2}$ ).

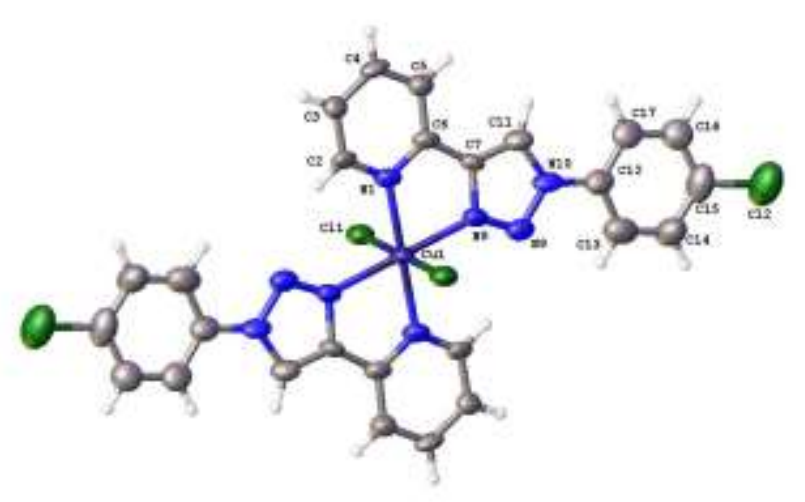


Figure 3. View of complex $\left[\mathrm{Cu}\left(\mathrm{L}^{6}\right)_{2} \mathrm{Cl}_{2}\right]$, showing the atom labelling scheme. The thermal ellipsoids are drawn at a $50 \%$ probability level and $H$ atoms are shown as small spheres of arbitrary size. Group $R=\mathrm{Cl}_{(\text {for }}$ ligand $\mathrm{L}^{6}$ ).

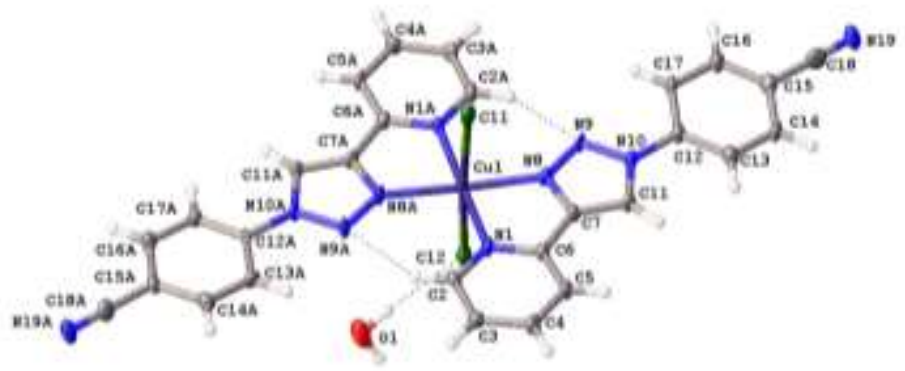

Figure 4. View of complex $\left[\mathrm{Cu}\left(\mathrm{L}^{7}\right)_{2} \mathrm{Cl}_{2}\right]$, showing the atom labelling scheme. The thermal ellipsoids are drawn at a $50 \%$ probability level and $H$ atoms are shown as small spheres of arbitrary size. Group $R=C N\left(\right.$ for ligand $L^{7}$ ).

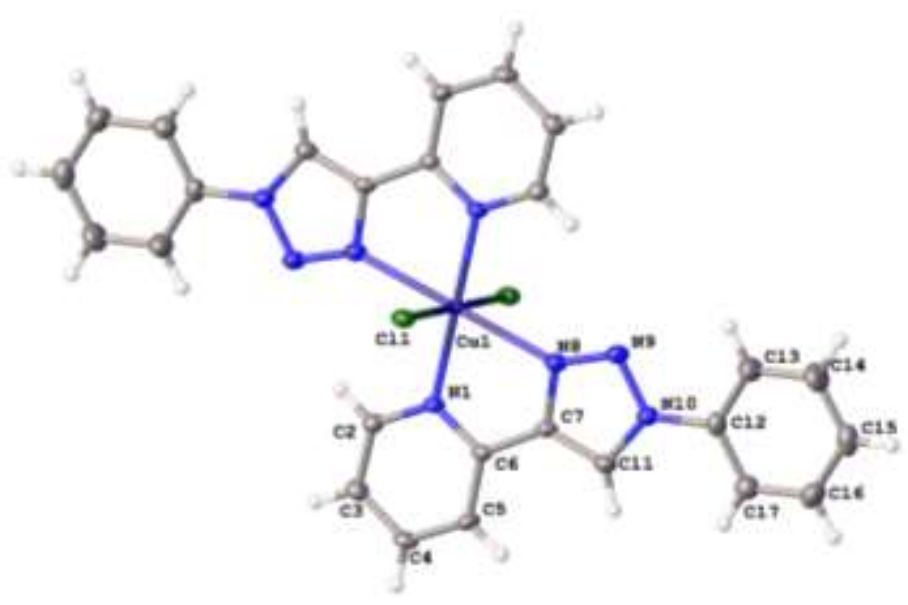

Figure 5. View of complex $\left[\mathrm{Cu}\left(\mathrm{L}^{8}\right)_{2} \mathrm{Cl}_{2}\right]$, showing the atom labelling scheme. The thermal ellipsoids are drawn at

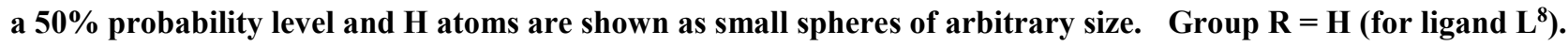




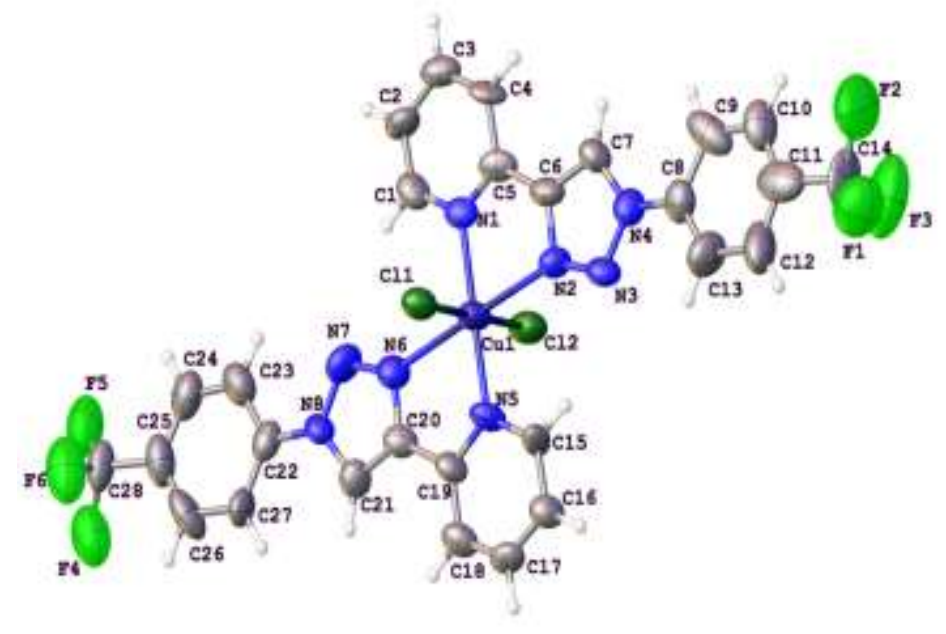

Figure 6. View of complex $\left[\mathrm{Cu}\left(\mathrm{L}^{9}\right)_{2} \mathrm{Cl}_{2}\right]$, showing the atom labelling scheme. The asymmetric unit contains half of the molecule, with the $\mathrm{Cu}$ atom lying on an inversion site. The thermal ellipsoids are drawn at a 50\% probability level and $H$ atoms are shown as small spheres of arbitrary size. Group $R=C_{3}$ (for ligand $L^{9}$ ).

In all the $\left[\mathrm{Cu}\left(\mathrm{L}^{\mathrm{n}}\right)_{2} \mathrm{Cl}_{2}\right]$ compounds of this study, the two 2-pyridyl-1,2,3-triazole ligands $\left(\mathrm{L}^{\mathrm{n}}\right)$ coordinated to the copper atom, lie trans to each other, with the two chloride ions as coligands also trans to each other. All structures display a Jahn-Teller distorted octahedral coordination. However, the Jahn-Teller distortion does not occur along the same bonds in the various crystal structures. Compounds $\left[\mathrm{Cu}\left(\mathrm{L}^{2}\right)_{2} \mathrm{Cl}_{2}\right],\left[\mathrm{Cu}\left(\mathrm{L}^{8}\right)_{2} \mathrm{Cl}_{2}\right]$ and $\left[\mathrm{Cu}\left(\mathrm{L}^{9}\right)_{2} \mathrm{Cl}_{2}\right]$ exhibit compression Jahn-Teller distortion along the copper- $\mathrm{N}\left(\right.$ pyridine) bonds $\left(\mathrm{Cu}-\mathrm{N}_{(P Y)}\right)$, while $\left[\mathrm{Cu}\left(\mathrm{L}^{6}\right)_{2} \mathrm{Cl}_{2}\right]$ and $\left[\mathrm{Cu}\left(\mathrm{L}^{7}\right)_{2} \mathrm{Cl}_{2}\right]$ exhibit elongation Jahn-Teller distortion along the copper-Cl bonds instead. See Figure 7 for an illustration of the Jahn-Teller distortion observed for the five compounds of this study, including a structure obtained from literature, $\left[\mathrm{Cu}(\text { pyta })_{2} \mathrm{Cl}_{2}\right]$ [11]. This structure of a previously reported related complex, namely dichloro-(2-((4-phenyl-1H-1,2,3-triazol-1-yl)methyl)pyridine-N,N')-copper(II), referred to as $\left[\mathrm{Cu}(\text { pyta })_{2} \mathrm{Cl}_{2}\right]$, [11], exhibits elongation Jahn-Teller distortion along the copper-N(triazole) bonds (contrary to the Jahn-Teller elongation found along the $\mathrm{Cu}-\mathrm{Cl}$ bonds, for complexes 6 and 7 from this study). However, elongation along the copper- $\mathrm{N}\left(\right.$ triazole) bonds in $\left[\mathrm{Cu}(\mathrm{pyta})_{2} \mathrm{Cl}_{2}\right]$ is possible, since the ligand of this complex, namely 2-[(4-phenyl-1H-1,2,3-triazol-1-yl)methyl]pyridine, contains a $\mathrm{CH}_{2}$ linkage between the 1,2,3-triazol and the pyridine groups, rendering it more flexible than the more rigid complexes from this study. For those five $\left[\mathrm{Cu}\left(\mathrm{L}^{\mathrm{n}}\right)_{2} \mathrm{Cl}_{2}\right]$ complexes of this study, elongation is not expected along either the copper-N(triazole) bonds, or the copper-N(pyridine) bonds since the 2-pyridyl-(1,2,3)-triazole ligands $\left(\mathrm{L}^{2}, \mathrm{~L}^{6}-\mathrm{L}^{9}\right)$ are more rigid. However, elongation along the copper- $\mathrm{Cl}$ bonds is possible, as has indeed been observed for complexes $\left[\mathrm{Cu}\left(\mathrm{L}^{6}\right)_{2} \mathrm{Cl}_{2}\right]$ and $\left[\mathrm{Cu}\left(\mathrm{L}^{7}\right)_{2} \mathrm{Cl}_{2}\right]$ from this study. 
The $\mathrm{Cu}-\mathrm{N}_{(P Y)}$ bond lengths were found to be $c a .1 .99 \AA$ for compounds $\left[\mathrm{Cu}\left(\mathrm{L}^{2}\right)_{2} \mathrm{Cl}_{2}\right],\left[\mathrm{Cu}\left(\mathrm{L}^{8}\right)_{2} \mathrm{Cl}_{2}\right]$ and $\left[\mathrm{Cu}\left(\mathrm{L}^{9}\right)_{2} \mathrm{Cl}_{2}\right]$, which exhibit compression Jahn-Teller distortion along this $\mathrm{Cu}-\mathrm{N}_{(P Y)}$ bond, while they were ca. $2.1 \AA$ for complexes $\left[\mathrm{Cu}\left(\mathrm{L}^{6}\right)_{2} \mathrm{Cl}_{2}\right]$ and $\left[\mathrm{Cu}\left(\mathrm{L}^{7}\right)_{2} \mathrm{Cl}_{2}\right]$ with elongation Jahn-Teller distortion along the copper- $\mathrm{Cl}$ bonds instead (a difference of $0.11 \AA$ for $\mathrm{Cu}-\mathrm{N}_{(P Y)}$ ). The $\mathrm{Cu}-\mathrm{Cl}$ bond lengths on the other hand were found to be $c a .2 .3 \AA$ for compounds $\left[\mathrm{Cu}\left(\mathrm{L}^{2}\right)_{2} \mathrm{Cl}_{2}\right],\left[\mathrm{Cu}\left(\mathrm{L}^{8}\right)_{2} \mathrm{Cl}_{2}\right]$ and $\left[\mathrm{Cu}\left(\mathrm{L}^{9}\right)_{2} \mathrm{Cl}_{2}\right]$ with compression Jahn-Teller distortion along $\mathrm{Cu}-\mathrm{N}_{(P Y)}$, while they were $c a .2 .6 \AA$ for $\left[\mathrm{Cu}\left(\mathrm{L}^{6}\right)_{2} \mathrm{Cl}_{2}\right]$ and $\left[\mathrm{Cu}\left(\mathrm{L}^{7}\right)_{2} \mathrm{Cl}_{2}\right]$ with elongation Jahn-Teller distortion along the copper- $\mathrm{Cl}$ bonds (a difference of $0.30 \AA$ for $\mathrm{Cu}-\mathrm{Cl}$ ). The $\mathrm{N} 8=\mathrm{N} 9$ and N9-N10 bonds inside the 1,2,3-triazole ring remained fairly constant at $c a .1 .30 \AA$ and $1.35 \AA$ respectively, while the $\mathrm{C} 7-\mathrm{C} 11$ bond varied very slightly between 1.36 and $1.39 \AA$, not showing any significant change due to the Jahn-Teller effect on the compounds (see Table 3). Neither did the bond angles and torsion angles (Table 4 and Table 5) show any significant differences due to the different geometry distortions in the compounds, caused by the Jahn-Teller effect.
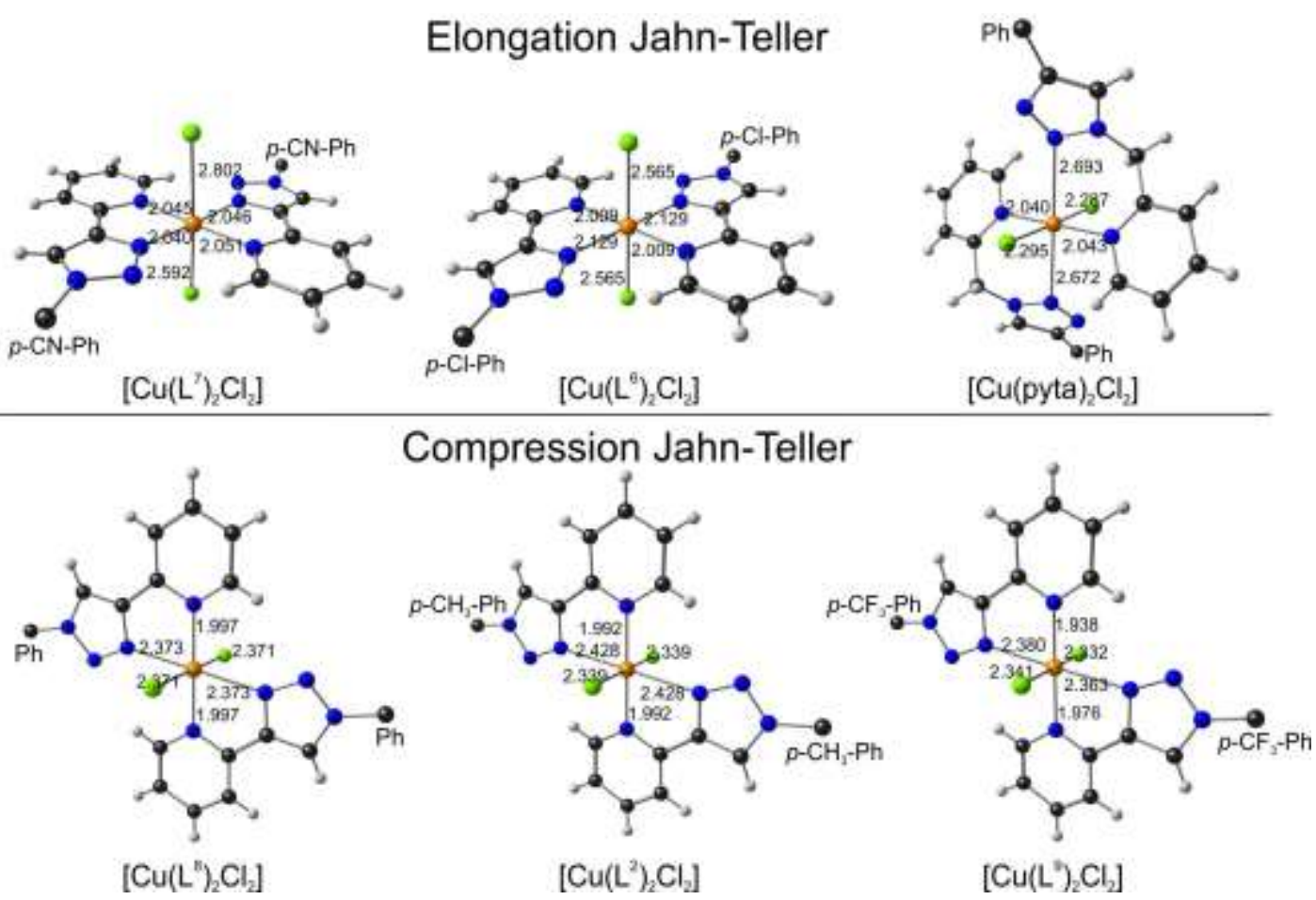

Figure 7. Illustration of the Jahn-Teller distortion observed for the five $\left[\mathrm{Cu}\left(\mathrm{L}^{\mathrm{n}}\right)_{2} \mathrm{Cl}_{2}\right]$ compounds (with ligands $\mathrm{L}^{\mathrm{n}}$

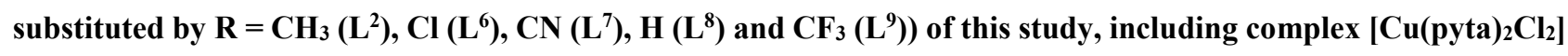
obtained from literature [11] (top right). Complexes with ligands $L^{7}$ and $L^{6}$ (above left) exhibit Jahn-Teller elongation, while complexes with ligands $L^{8}, L^{2}$ and $L^{9}$ (below) exhibit Jahn-Teller compression.

Table 2. Crystallographic data of $\left[\mathrm{Cu}\left(\mathrm{L}^{\mathrm{n}}\right)_{2} \mathrm{Cl}_{2}\right]$ compounds (with ligand substituents $\mathrm{R}=\mathrm{CH}_{3}\left(\mathrm{~L}^{2}\right), \mathrm{Cl}\left(\mathrm{L}^{6}\right), \mathrm{CN}$ $\left(L^{7}\right), H\left(L^{8}\right)$ and $\left.C F_{3}\left(L^{9}\right)\right)$. 


\begin{tabular}{|c|c|c|c|c|c|}
\hline Compound & {$\left[\mathrm{Cu}\left(\mathrm{L}^{2}\right)_{2} \mathrm{Cl}_{2}\right]$} & {$\left[\mathrm{Cu}\left(\mathrm{L}^{6}\right)_{2} \mathrm{Cl}_{2}\right]$} & {$\left[\mathrm{Cu}\left(\mathrm{L}^{7}\right)_{2} \mathrm{Cl}_{2}\right.$} & {$\left[\mathrm{Cu}\left(\mathrm{L}^{8}\right)_{2} \mathrm{Cl}_{2}\right]$} & {$\left[\mathrm{Cu}\left(\mathrm{L}^{9}\right)_{2} \mathrm{Cl}_{2}\right]$} \\
\hline Formula & $\mathrm{C}_{28} \mathrm{H}_{24} \mathrm{Cl}_{2} \mathrm{CuN}_{8}$ & $\mathrm{C}_{26} \mathrm{H}_{18} \mathrm{Cl}_{4} \mathrm{Cu}_{1} \mathrm{~N}_{8}$ & $\mathrm{C}_{28} \mathrm{H}_{20} \mathrm{Cl}_{2} \mathrm{CuN}_{10} \mathrm{O}$ & $\mathrm{C}_{26} \mathrm{H}_{20} \mathrm{Cl}_{2} \mathrm{CuN}_{8}$ & $\mathrm{C}_{28} \mathrm{H}_{18} \mathrm{Cl}_{2} \mathrm{CuN}_{8} \mathrm{~F}_{6}$ \\
\hline$M_{\mathrm{r}}$ & 606.99 & 647.84 & 646.98 & 578.94 & 714.94 \\
\hline Temp (K) & $120(2) \mathrm{K}$ & $100 \mathrm{~K}$ & $100(2) \mathrm{K}$ & 293(2) K & $100(2) \mathrm{K}$ \\
\hline Wavelength $(\AA)$ & 0.71073 & 0.71075 & 0.71075 & 0.71075 & 0.68890 \\
\hline Cryst. syst. & Monoclinic & Orthorhombic & triclinic & Monoclinic & Orthorhombic \\
\hline Space group & $\mathrm{P} 21 / \mathrm{c}$ & Pccn & $\mathrm{P}-1$ & $\mathrm{P} 21 / \mathrm{c}$ & Pca21 \\
\hline$a / \AA$ & $11.3032(7)$ & $12.5664(12)$ & $11.2493(8)$ & $10.4068(7)$ & $9.544(11)$ \\
\hline$b / \AA ̊$ & $12.7346(8)$ & $25.691(3)$ & $11.5300(8)$ & $12.7681(6)$ & $12.724(14)$ \\
\hline$c / \AA$ & $9.8024(5)$ & $9.7169(9)$ & $12.0137(8)$ & $9.4738(5)$ & $22.54(3)$ \\
\hline$\alpha /^{\circ}$ & 90.00 & 90.00 & $110.065(8)^{\circ}$ & 90.00 & 90.00 \\
\hline$\beta /^{\circ}$ & $108.759(4)^{\circ}$ & 90.00 & $99.450(7)^{\circ}$ & $107.058(8)$ & 90.00 \\
\hline$\gamma /{ }^{\circ}$ & 90.00 & 90.00 & $105.122(7)^{\circ}$ & 90.00 & 90.00 \\
\hline$V / \AA^{3}$ & $1336.02(14)$ & $3137.0(6)$ & $1356.5(3)$ & $1203.45(12)$ & $2738(5)$ \\
\hline$Z$ & 2 & 4 & 2 & 2 & 4 \\
\hline$R_{\text {int }}$ & 0.0586 & 0.0950 & 0.081 & 0.0351 & 0.1333 \\
\hline$D_{\text {calcd }}\left(\mathrm{gcm}^{-3}\right)$ & 1.509 & 1.372 & 1.584 & 1.598 & 1.735 \\
\hline Refln (all/ind) & $12104 / 3036$ & $7213 / 2863$ & $16775 / 16760$ & $6760 / 2718$ & $17238 / 4620$ \\
\hline$\mu\left(\mathrm{mm}^{-1}\right)$ & 1.052 & 1.066 & 1.047 & 1.164 & 1.072 \\
\hline $\begin{array}{l}R 1 / w R 2 \\
\text { (observed data: } \\
F^{2}>2 \sigma\left(F^{2}\right) \text { ) }\end{array}$ & $0.0637 / 0.1140$ & $0.0879 / 0.2132$ & $0.0778 / 0.1875$ & $0.0378 / 0.0801$ & $0.1135 / 0.2970$ \\
\hline $\begin{array}{l}R 1 / w R 2 \\
\text { (all data) }\end{array}$ & $0.0958 / 0.1300$ & $0.1882 / 0.2614$ & $0.1350 / 0.2192$ & $0.0513 / 0.0878$ & $0.1266 / 0.3128$ \\
\hline
\end{tabular}

Table 3. Selected bond lengths $(\AA)$ of $\left[\mathrm{Cu}\left(\mathrm{L}^{\mathrm{n}}\right)_{2} \mathrm{Cl}_{2}\right]$ compounds (with ligand substituents $\mathrm{R}=\mathrm{CH}_{3}\left(\mathrm{~L}^{2}\right), \mathrm{Cl}_{\left(\mathrm{L}^{6}\right), \mathrm{CN}^{-}}$ $\left(\mathrm{L}^{7}\right), \mathrm{H}\left(\mathrm{L}^{8}\right)$ and $\left.\mathrm{CF}_{3}\left(\mathrm{~L}^{9}\right)\right)$.

\begin{tabular}{|c|c|c|c|c|c|}
\hline Bonds $^{\mathrm{a}}$ & {$\left[\mathrm{Cu}\left(\mathrm{L}^{2}\right)_{2} \mathrm{Cl}_{2}\right]$} & {$\left[\mathrm{Cu}\left(\mathrm{L}^{6}\right)_{2} \mathrm{Cl}_{2}\right]$} & {$\left[\mathrm{Cu}\left(\mathrm{L}^{7}\right)_{2} \mathrm{Cl}_{2}\right]$} & {$\left[\mathrm{Cu}\left(\mathrm{L}^{8}\right)_{2} \mathrm{Cl}_{2}\right]$} & {$\left[\mathrm{Cu}\left(\mathrm{L}^{9}\right)_{2} \mathrm{Cl}_{2}\right]$} \\
\hline & $\mathrm{C}_{28} \mathrm{H}_{24} \mathrm{Cl}_{2} \mathrm{CuN}_{8}$ & $\mathrm{C}_{26} \mathrm{H}_{18} \mathrm{Cl}_{4} \mathrm{Cu}_{1} \mathrm{~N}_{8}$ & $\mathrm{C}_{28} \mathrm{H}_{20} \mathrm{Cl}_{2} \mathrm{CuN}_{10} \mathrm{O}$ & $\mathrm{C}_{26} \mathrm{H}_{20} \mathrm{Cl}_{2} \mathrm{CuN}_{8}$ & $\mathrm{C}_{28} \mathrm{H}_{18} \mathrm{Cl}_{2} \mathrm{CuN}_{8} \mathrm{~F}_{6}$ \\
\hline $\mathrm{C}_{(\text {triazole })} 7-\mathrm{C}_{(\text {triazole })} 11$ & $1.367(6)$ & $1.363(10)$ & $1.378(8)$ & $1.371(3)$ & $1.393(16)$ \\
\hline $\mathrm{N}_{(\text {triazole })} 8-\mathrm{N}_{(\text {triazole })} 9$ & $1.312(5)$ & $1.299(9)$ & $1.338(7)$ & $1.308(3)$ & $1.295(12)$ \\
\hline $\mathrm{N}_{(\text {triazole })} 9-\mathrm{N}_{(\text {triazole })} 10$ & $1.358(5)$ & $1.361(9)$ & $1.350(7)$ & $1.354(3)$ & $1.349(13)$ \\
\hline $\mathrm{N}_{(\text {triazole })} 8-\mathrm{C}_{(\text {triazole })} 7$ & $1.356(5)$ & $1.360(9)$ & $1.357(7)$ & $1.362(3)$ & $1.371(15)$ \\
\hline $\mathrm{N}_{(P Y)} 1-\mathrm{C}_{(P Y)} 6$ & $1.344(5)$ & $1.363(10)$ & $1.347(8)$ & $1.356(3)$ & $1.286(15)$ \\
\hline $\mathrm{Cu}-\mathrm{N}_{(P Y)} 1$ & $1.992(3)$ & $2.010(6)$ & $2.045(5)$ & $1.997(18)$ & $1.976(10)$ \\
\hline $\mathrm{Cu}-\mathrm{N}_{(P Y)} 1^{\mathrm{i}}$ & $1.992(3)$ & $2.010(6)$ & $2.051(5)$ & $1.9970(18)$ & $1.938(10)$ \\
\hline $\mathrm{Cu}-\mathrm{N}_{(\text {triazole })} 8$ & $2.428(3)$ & $2.130(7)$ & $2.051(5)$ & $2.3724(19)$ & $2.363(9)$ \\
\hline $\mathrm{Cu}-\mathrm{N}_{(\text {triazole })} 8^{\mathrm{i}}$ & $2.428(3)$ & $2.130(7)$ & $2.047(5)$ & $2.3724(19)$ & $2.381(9)$ \\
\hline $\mathrm{Cu}-\mathrm{Cll}$ & $2.3394(10)$ & $2.565(2)$ & $2.8024(19)$ & $2.3711(6)$ & $2.332(4)$ \\
\hline $\mathrm{Cu}-\mathrm{Cl} 2^{\mathrm{i}}$ & $2.3394(10)$ & $2.565(2)$ & $2.5922(18)$ & $2.3710(6)$ & $2.341(5)$ \\
\hline
\end{tabular}

a Atom numbering according to Figure 5.

Table 4. Selected angles $\left[^{\circ}\right]$ of $\left[\mathrm{Cu}\left(\mathrm{L}^{\mathrm{n}}\right)_{2} \mathrm{Cl}_{2}\right]$ compounds (with ligand substituents $\mathrm{R}=\mathrm{CH}_{3}\left(\mathrm{~L}^{2}\right), \mathrm{Cl}\left(\mathrm{L}^{6}\right), \mathrm{CN}\left(\mathrm{L}^{7}\right)$, $\mathrm{H}\left(\mathrm{L}^{8}\right)$ and $\left.\mathrm{CF}_{3}\left(\mathrm{~L}^{9}\right)\right)$.

\begin{tabular}{|c|c|c|c|c|c|}
\hline Angles $^{\mathrm{a}}$ & {$\left[\mathrm{Cu}\left(\mathrm{L}^{2}\right)_{2} \mathrm{Cl}_{2}\right]$} & {$\left[\mathrm{Cu}\left(\mathbf{L}^{6}\right)_{2} \mathrm{Cl}_{2}\right]$} & {$\left[\mathrm{Cu}\left(\mathrm{L}^{7}\right)_{2} \mathrm{Cl}_{2}\right]$} & {$\left[\mathrm{Cu}\left(\mathrm{L}^{8}\right)_{2} \mathrm{Cl}_{2}\right]$} & {$\left[\mathrm{Cu}\left(\mathrm{L}^{9}\right)_{2} \mathrm{Cl}_{2}\right]$} \\
\hline $\mathrm{N}_{(P Y)} 1-\mathrm{Cu}-\mathrm{N}_{(P Y)} 1^{\mathrm{i}}$ & $180.000(1)$ & 180.0 & $177.8(2)$ & $180.00(2)$ & $179.2(5)$ \\
\hline 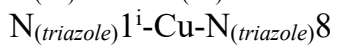 & $180.00(19)$ & $180.0(2)$ & $176.1(2)$ & $180.00(8)$ & $178.7(4)$ \\
\hline $\left.\mathrm{N}_{(P Y)} 1-\mathrm{Cu}-\mathrm{N}_{(\text {triazole })}\right)^{\mathrm{i}}$ & 101.94(12) & $99.8(3)$ & $99.60(19)$ & $101.89(7)$ & $103.8(4)$ \\
\hline $\mathrm{N}_{(P Y)} 1-\mathrm{Cu}-\mathrm{N}_{(\text {triazole })} 8$ & $78.06(12)$ & $80.2(3)$ & $80.24(19)$ & $78.11(7)$ & $77.4(3)$ \\
\hline $\mathrm{N}_{(P Y)} 1-\mathrm{Cu}-\mathrm{Cl} 1$ & $90.47(9)$ & $89.50(19)$ & $86.01(15)$ & $89.01(6)$ & $88.0(2)$ \\
\hline 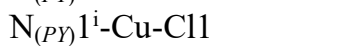 & $89.53(9)$ & $90.50(19)$ & $91.77(15)$ & $90.99(6)$ & $92.0(3)$ \\
\hline 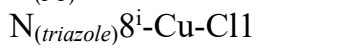 & $88.44(10)$ & $88.28(5)$ & $91.77(15)$ & $88.28(5)$ & $89.7(3)$ \\
\hline $\mathrm{N}_{\text {(triazole })} 8-\mathrm{Cu}-\mathrm{Cl} 1$ & $91.56(10)$ & $92.11(18)$ & $84.52(14)$ & $91.72(5)$ & $90.1(3)$ \\
\hline $\mathrm{Cl1}{ }^{\mathrm{i}}-\mathrm{M}-\mathrm{Cl} 1$ & 180.0 & 180.0 & $176.80(6)$ & $179.999(10)$ & $179.03(13)$ \\
\hline $\mathrm{N}_{(P Y)} 1-\mathrm{Cu}-\mathrm{Cl} 2$ & $89.53(9)$ & $90.50(19)$ & $92.57(15)$ & $90.99(6)$ & $91.4(2)$ \\
\hline
\end{tabular}




\begin{tabular}{llllll}
\hline $\mathrm{N}($ triazole $) 8-\mathrm{Cu}-\mathrm{Cl} 2$ & $88.44(10)$ & $87.89(18)$ & $92.42(14)$ & $88.28(5)$ & $90.6(3)$ \\
\hline
\end{tabular}

a Atom numbering according to Figure 5.

Table 5. Torsion angles $\left[^{\circ}\right]$ of $\left[\mathrm{Cu}\left(\mathrm{L}^{\mathrm{n}}\right)_{2} \mathrm{Cl}_{2}\right]$ compounds (with ligand substituents $\mathrm{R}=\mathrm{CH}_{3}\left(\mathrm{~L}^{2}\right), \mathrm{Cl}\left(\mathrm{L}^{6}\right), \mathrm{CN}\left(\mathrm{L}^{7}\right)$, $H\left(L^{8}\right)$ and $\left.C F_{3}\left(L^{9}\right)\right)$.

\begin{tabular}{|c|c|c|c|c|c|}
\hline Torsion angles $^{\mathbf{a}}$ & {$\left[\mathrm{Cu}\left(\mathrm{L}^{2}\right)_{2} \mathrm{Cl}_{2}\right]$} & {$\left[\mathrm{Cu}\left(\mathrm{L}^{6}\right)_{2} \mathrm{Cl}_{2}\right]$} & {$\left[\mathrm{Cu}\left(\mathrm{L}^{7}\right)_{2} \mathrm{Cl}_{2}\right]$} & {$\left[\mathrm{Cu}\left(\mathrm{L}^{8}\right)_{2} \mathrm{Cl}_{2}\right]$} & {$\left[\mathrm{Cu}\left(\mathrm{L}^{9}\right)_{2} \mathrm{Cl}_{2}\right]$} \\
\hline Cu1-N1-C6-C7 & $1.3(5)$ & $2.3(9)$ & $1.6(7)$ & $1.3(3)$ & $0.0(12)$ \\
\hline Cu1-N8-N9-N10 & $177.5(4)$ & $-172.8(6)$ & $-178.0(4)$ & $-169.6(2)$ & $170.5(10)$ \\
\hline $\mathrm{Cu} 1-\mathrm{N} 8-\mathrm{C} 7-\mathrm{C} 6$ & $0.6(4)$ & $-6.2(8)$ & $-2.6(7)$ & $-6.4(3)$ & $4.7(12)$ \\
\hline N8-N9-N10-C12 & $-178.2(4)$ & $-177.9(7)$ & $177.7(5)$ & $-179.2(2)$ & $177.4(9)$ \\
\hline C7-N8-N9-N10 & $-0.6(5)$ & $0.0(8)$ & $0.8(7)$ & $-0.2(4)$ & $2.7(12)$ \\
\hline N9-N10-C12-C17 & $0.2(7)$ & $177.8(7)$ & $8.3(9)$ & $-178.1(2)$ & $173.5(10)$ \\
\hline N1-C6-C7-N8 & $-1.3(6)$ & $2.9(10)$ & $0.7(9)$ & $4.3(3)$ & $-3.9(15)$ \\
\hline N8-N9-N10-C12 & $-178.2(4)$ & $-1.0(8)$ & $177.7(5)$ & $-179.2(2)$ & $177.4(9)$ \\
\hline N8-N9-N10-C11 & $0.5(5)$ & $-177.9(7)$ & $-0.1(7)$ & $0.0(3)$ & $2.7(12)$ \\
\hline
\end{tabular}

a Atom numbering according to Figure 5.

The packing of the $\left[\mathrm{Cu}\left(\mathrm{L}^{2}\right)_{2} \mathrm{Cl}_{2}\right]$ compound (with ligand substituent $\mathrm{R}=\mathrm{CH}_{3}$ ) is discussed here, as an example of the packing observed in the solid state for all the $\left[\mathrm{Cu}\left(\mathrm{L}^{\mathrm{n}}\right)_{2} \mathrm{Cl}_{2}\right]$ compounds $\left(\mathrm{L}^{\mathrm{n}}=\mathrm{L}^{2}, \mathrm{~L}^{6}\right.$, $\mathrm{L}^{7}, \mathrm{~L}^{8}$ and $\mathrm{L}^{9}$ ) of this study. The molecules are arranged in a head to tail arrangement, similar to the arrangements reported for complexes of $\mathrm{Ni}(\mathrm{II}), \mathrm{Co}(\mathrm{II})$ and $\mathrm{Zn}$ (II) metals with these pyridyl-triazole ligands $[6,7,20]$. The crystal structure of the $\left[\mathrm{Cu}\left(\mathrm{L}^{2}\right)_{2} \mathrm{Cl}_{2}\right]$ complex is governed by extensive hydrogen bonding $\mathrm{C}-\mathrm{H}$... $\mathrm{Cl}$ interactions, between the chloride coligands which are bound to the copper centres of one molecule, and three of the nearest $\mathrm{C}-\mathrm{H}$ bonds on the $\mathrm{L}^{2}$ ligand of a neighbouring molecule, as well as to a $\mathrm{C}-\mathrm{H}$ bond of a methyl substituent on another adjacent molecule; see Figure 6 . The molecules involved in the hydrogen bonds are the following:

(1) the $\mathrm{C}-\mathrm{H}(\mathrm{C} 7-\mathrm{H} 7)$ atoms of the triazole ring as donor and the chloride ligand of a neighbouring molecule as acceptor;

(2) the $\mathrm{C}-\mathrm{H}(\mathrm{C} 4-\mathrm{H} 4)$ atoms of the pyridine ring as donor and the chloride ligand of a neighbouring molecule as acceptor;

(3) the $\mathrm{C}-\mathrm{H}(\mathrm{C} 9-\mathrm{H} 9)$ atoms of the phenyl ring as donor and the chloride ligand of a neighbouring molecule as acceptor;

(4) $\mathrm{C}-\mathrm{H}(\mathrm{C} 14-\mathrm{H} 14 \mathrm{C})$ atoms of the methyl group (on $\left.\mathrm{L}^{2}\right)$ as a donor and the chloride ligand of another adjacent molecule as acceptor.

Relevant bond distances and angles are listed in Table 6. It follows from these $\mathrm{C}-\mathrm{H}$...Cl values in Table 6, that the distances between the proton and the acceptor atoms $(\mathrm{H} . . . \mathrm{Cl}=c a .2 .89 \AA)$ are mostly longer than the sum of their van der Waals radii $(2.75 \AA)$; however the $\mathrm{C}-\mathrm{H}$...Cl linkages of the 
triazole rings $(\mathrm{H} . . . \mathrm{Cl}=2.430(9) \AA)$ displayed shorter distances than the sum of their van der Waals radii $(2.75 \AA)[21,22]$. The molecules of the $\left[\mathrm{Cu}\left(\mathrm{L}^{2}\right)_{2} \mathrm{Cl}_{2}\right]$ complex are arranged in infinite hydrogenbonded chains, with the $\mathrm{C}-\mathrm{H}$... $\mathrm{Cl}$ interactions between the molecules of $\left[\mathrm{Cu}\left(\mathrm{L}^{2}\right)_{2} \mathrm{Cl}_{2}\right]$ adopting a headto-tail orientation, as shown in Figure 8 by green and white spheres. This generates a 3D network, which is governed by weak intermolecular hydrogen bonds [23][24]. The compound is stabilized by these hydrogen bonding interactions, as well as by intermolecular $\pi$... $\pi$ stacking between the triazole and pyridyl rings in the solid state. The overlap between a triazole- and phenyl-ring of adjacent molecules, adopts an offset-slipped parallel displaced version where the centroid-centroid distance is $4.105 \AA$. This distance is comparable to the previously reported bond separation of a typical $\pi \ldots \pi$ stacking $[25,26,27,28]$. The centroid-plane perpendicular distance is $3.508 \AA$, with an angle between the two planes of $10.83^{\circ}$; see Figure 8 .

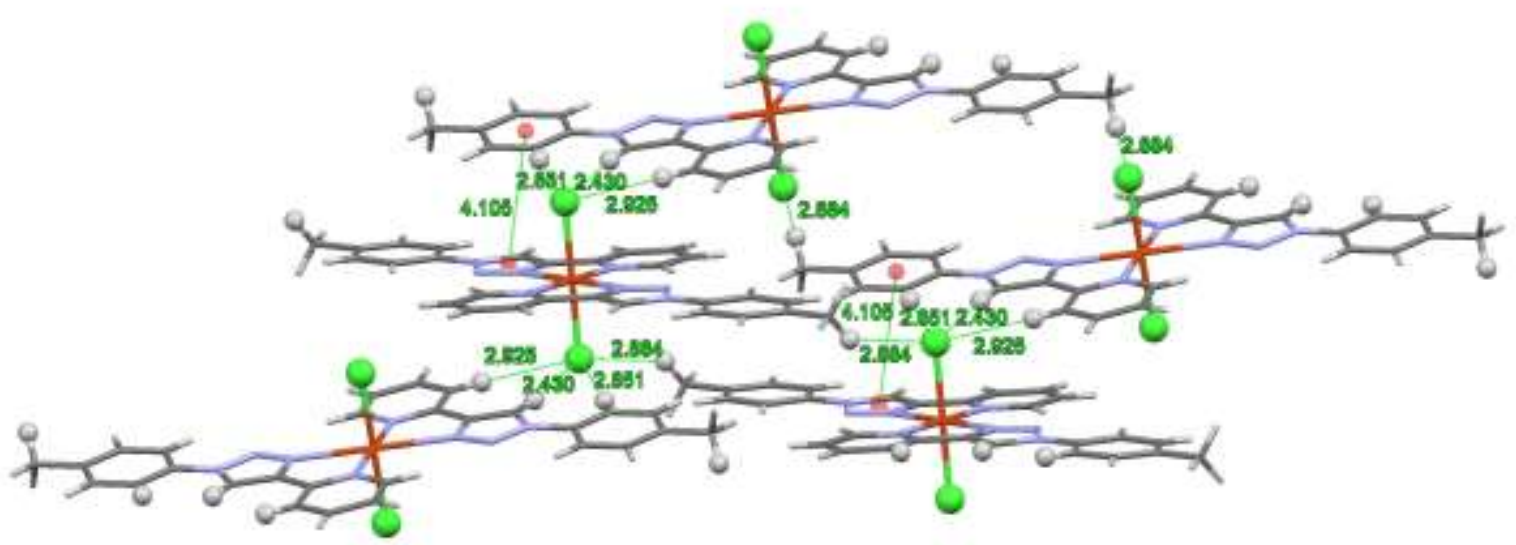

Figure 8. Packing of the $\left[\mathrm{Cu}\left(\mathrm{L}^{2}\right)_{2} \mathrm{Cl}_{2}\right]$ molecules, indicating intermolecular hydrogen bonding, as well as the $\pi$... stacking interactions. Selected $\mathrm{Cl}$ (green) and $\mathrm{H}$ (white) atoms involved in intermolecular interactions, are indicated by green and white spheres.

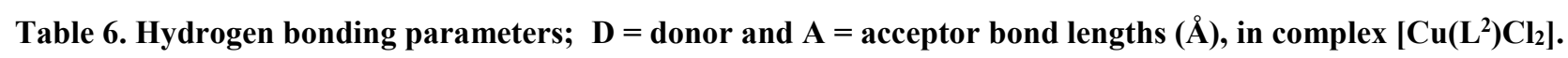

\begin{tabular}{lllll}
\hline D-H...A & D-H & H-A & D-A & Angle (o) \\
\hline C7-H7..Cl1 & $0.950(4)$ & $2.430(9)$ & $3.373(4)$ & $172.3(2)$ \\
C4-H4..Cl1 & $0.950(4)$ & $2.925(2)$ & $3.864(4)$ & $169.8(2)$ \\
C9-H9..Cl1 & $0.950(4)$ & $2.850(9)$ & $3.794(4)$ & $172.2(2)$ \\
C14-H14...Cl1 & $0.980(5)$ & $2.884(9)$ & $3.675(5)$ & $138.3(3)$ \\
Cu-Cl-H7 & & & & $107.03(4)$ \\
Cu-Cl-H4 & & & & $98.55(3)$ \\
Cu-Cl-H9 & & & & $105.23(4)$ \\
Cu-Cl-H14 & & & & $102.02(4)$ \\
\hline
\end{tabular}




\subsection{DFT study}

A density functional theory study was conducted on all the $\left[\mathrm{Cu}\left(\mathrm{L}^{\mathrm{n}}\right)_{2} \mathrm{Cl}_{2}\right]$ compounds of this study (namely $\mathrm{L}^{2}=2$-(1-(p-tolyl)-1H-1,2,3-triazol-4-yl)pyridine), $\mathrm{L}^{6}=2$-(1-(4-chlorophenyl)-1H-1,2,3triazol-4-yl)pyridine), $\mathrm{L}^{7}=$ of 4-(4-(pyridin-2-yl)-1H-1,2,3-triazol-4-yl)benzonitril), $\mathrm{L}^{8}=2-(1$ phenyl-1H-1,2,3-triazol-4-yl)pyridine) and $\mathrm{L}^{9}=$ - -(1-(4-(trifluoromethyl)phenyl)-1H-1,2,3-triazol-4yl)pyridine), in order to gain further insight into the observed Jahn-Teller distortion along different bonds of these compounds. The Jahn-Teller distortion theoretically is possible along any two opposite bonds in these octahedral compounds, i.e. along the $\mathrm{Cu}-\mathrm{N}$ (pyridine) bonds or the $\mathrm{Cu}-\mathrm{Cl}$ bonds or the $\mathrm{Cu}-\mathrm{N}($ triazole) bonds. It was possible to obtain three different Jahn-Teller distorted optimized geometries without any imaginary frequencies (i.e. true minima on the PES), for each of the five $\left[\mathrm{Cu}\left(\mathrm{L}^{\mathrm{n}}\right)_{2} \mathrm{Cl}_{2}\right]$ compounds. See Figure 9 for an illustration of the three geometries obtained for complex $\left[\mathrm{Cu}\left(\mathrm{L}^{8}\right)_{2} \mathrm{Cl}_{2}\right]$ as an example, and see Table 7 for the relative energies of the different geometries for all five complexes. Computational chemistry calculations clearly predict the geometry with compression Jahn-Teller distortion along the $\mathrm{Cu}-\mathrm{N}$ (pyridine) bonds, to be the favoured absolute minimum energy geometry, as has indeed been obtained experimentally, for compounds $\left[\mathrm{Cu}\left(\mathrm{L}^{2}\right)_{2} \mathrm{Cl}_{2}\right],\left[\mathrm{Cu}\left(\mathrm{L}^{8}\right)_{2} \mathrm{Cl}_{2}\right]$ and $\left[\mathrm{Cu}\left(\mathrm{L}^{9}\right)_{2} \mathrm{Cl}_{2}\right]$. On the contrary, the higher energy geometry $(\mathrm{ca}$. 0.50 $\mathrm{eV}$ relative to the minimum energy) with Jahn-Teller distortion along the copper-Cl bonds, has also been found experimentally, for complexes $\left[\mathrm{Cu}\left(\mathrm{L}^{6}\right)_{2} \mathrm{Cl}_{2}\right]$ and $\left[\mathrm{Cu}\left(\mathrm{L}^{7}\right)_{2} \mathrm{Cl}_{2}\right]$. We believe that the packing forces and intermolecular interactions in the solid state (Section 3.2) contributed to the unexpectedly stable existence of the higher energy geometry for both $\left[\mathrm{Cu}\left(\mathrm{L}^{6}\right)_{2} \mathrm{Cl}_{2}\right]$ and $\left[\mathrm{Cu}\left(\mathrm{L}^{7}\right)_{2} \mathrm{Cl}_{2}\right]$ in the solid state.

(a)

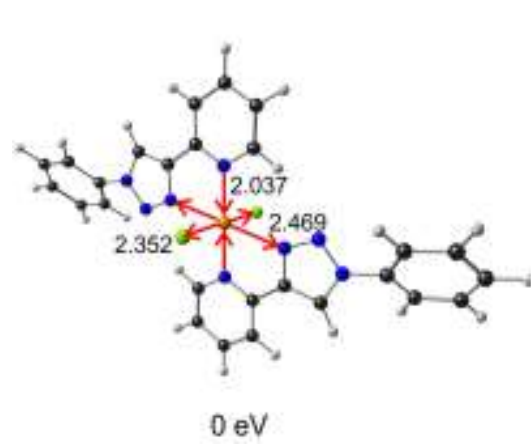

(b)

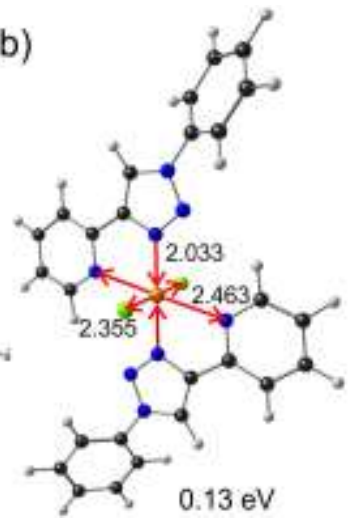

(c)

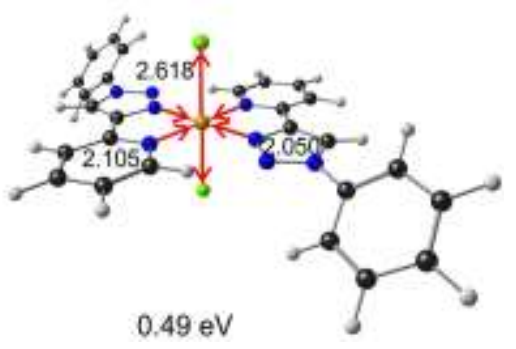

Figure 9. DFT calculated B3LYP/6-311G(d,p.) optimized geometries for complex $\left[\mathrm{Cu}\left(\mathrm{L}^{8}\right)_{2} \mathrm{Cl}_{2}\right]$, showing JahnTeller distortion along the (a) $\mathrm{Cu}-\mathrm{N}$ (pyridine), (b) $\mathrm{Cu}-\mathrm{N}$ (triazole) and (c) $\mathrm{Cu}-\mathrm{Cl}$ bonds. The DFT relative energies $(\mathrm{eV})$ for the different geometries are indicated below each geometry. 
Table 7. DFT calculated B3LYP/6-311G(d,p.) relative energies (eV) obtained for the indicated geometries in each of the $\left[\mathrm{Cu}\left(\mathrm{L}^{\mathrm{n}}\right)_{2} \mathrm{Cl}_{2}\right]$ compounds, with Jahn-Teller distortion along the specified pairs of opposite bonds.

\begin{tabular}{lllll}
\hline Compound & \multicolumn{3}{l}{ Jahn-Teller distortion along bonds } & \\
\cline { 2 - 4 } & $\begin{array}{l}\mathrm{Cu}-\mathrm{N} \text { (pyridine) } \\
\text { (compression) }\end{array}$ & $\begin{array}{l}\mathrm{Cu}-\mathrm{N} \text { (triazole) } \\
\text { (compression) }\end{array}$ & $\begin{array}{l}\mathrm{Cu}-\mathrm{Cl} \\
\text { (elongation) }\end{array}$ & $\mathrm{R}$ \\
\hline$\left[\mathrm{Cu}\left(\mathrm{L}^{2}\right)_{2} \mathrm{Cl}_{2}\right]$ & 0.00 & 0.13 & $\mathrm{a}$ & $\mathrm{CH}_{3}$ \\
{$\left[\mathrm{Cu}\left(\mathrm{L}^{6}\right)_{2} \mathrm{Cl}_{2}\right]$} & 0.00 & 0.14 & 0.51 & $\mathrm{Cl}$ \\
{$\left[\mathrm{Cu}\left(\mathrm{L}^{7}\right)_{2} \mathrm{Cl}_{2}\right]$} & 0.00 & 0.15 & 0.55 & $\mathrm{CN}$ \\
{$\left[\mathrm{Cu}\left(\mathrm{L}^{8}\right)_{2} \mathrm{Cl}_{2}\right]$} & 0.00 & 0.13 & 0.49 & $\mathrm{H}$ \\
{$\left[\mathrm{Cu}\left(\mathrm{L}^{9}\right)_{2} \mathrm{Cl}_{2}\right]$} & 0.00 & 0.15 & 0.53 & $\mathrm{CF}_{3}$ \\
\hline
\end{tabular}

a Converged to compression Jahn-Teller distortion along the $\mathrm{Cu}-\mathrm{N}$ (pyridine) bonds

\section{Summary}

The experimental solid state X-ray structures of five low-spin paramagnetic 2-pyridyl-(1,2,3)triazole-copper complexes, $\left[\mathrm{Cu}\left(\mathrm{L}^{\mathrm{n}}\right)_{2} \mathrm{Cl}_{2}\right]$, each containing two bidentate 2-pyridyl-(1,2,3)-triazole and two chloride ions as ligands, all demonstrate Jahn-Teller distortion, as is expected for octahedral $\mathrm{d}^{9}$ $\mathrm{Cu}$ (II) compounds. Quantum chemistry calculations, using density functional theory, identified at least three Jahn-Teller distorted geometries for each of the complexes in theory: namely a geometry with compression Jahn-Teller distortion along opposite $\mathrm{Cu}-\mathrm{N}$ (pyridine) bonds, a geometry with compression Jahn-Teller distortion along opposite $\mathrm{Cu}-\mathrm{N}$ (triazole) bonds and a geometry with elongation Jahn-Teller distortion along opposite $\mathrm{Cu}-\mathrm{Cl}$ bonds. The DFT calculations further showed that the geometry with compression Jahn-Teller distortion along opposite $\mathrm{Cu}-\mathrm{N}$ (pyridine) bonds is most stable with the lowest energy, while the geometry with elongation Jahn-Teller distortion along opposite $\mathrm{Cu}-\mathrm{Cl}$ bonds has the highest energy ( $c a .0 .50 \mathrm{eV}$ higher) and is therefore the most unstable geometry. However, the experimentally obtained structures presented in this study, unexpectedly both displayed the DFT calculated lowest energy (most stable) geometry with compression JahnTeller distortion along opposite $\mathrm{Cu}-\mathrm{N}$ (pyridine) bonds, as well as the DFT calculated highest energy (less stable) geometry with elongation Jahn-Teller distortion along opposite $\mathrm{Cu}-\mathrm{Cl}$ bonds. Many intermolecular interactions were observed in the solid state, which could have contributed to the unexpected existence of this more unstable higher energy geometry in the latter case. 


\section{Supplementary material}

Experimental IR, UV/vis spectra, MS, additional crystallographic data and optimized coordinates of the DFT calculations.

\section{Acknowledgements}

The National Mass Spectroscopy Centre at the University of Wales, Swansea, is thanked for supplying the mass spectrometry data. XRD data and structures were supplied by the National Crystallography Service at the University of Southampton. KT expresses his gratitude to the Iraqi Government for financial support to conduct the reported research in the UK. This work has received support from the South African National Research Foundation and the Central Research Fund of the University of the Free State, Bloemfontein, South Africa. The High Performance Computing facility of the University of the Free State and the Centre for High Performance Computing CHPC of South Africa, are gratefully acknowledged for computer time.

\section{References}

[1] H.A. Jahn, E. Teller, Stability of Polyatomic Molecules in Degenerate Electronic States. I. Orbital Degeneracy, Proceedings of the Royal Society of London, 1934-1990. Series A, Mathematical and Physical Sciences, 161 (1937) 220-235. DOI:10.1098/rspa.1937.0142

[2] M.A. Halcrow, Jahn-Teller distortions in transition metal compounds, and their importance in functional molecular and inorganic materials, Chem. Soc. Rev. 42 (2013) 1784-1795. DOI:10.1039/c2cs35253b

[3] R.J. Deeth, L.J.A. Hearnshaw, Molecular modelling of Jahn-Teller distortions in $\mathrm{Cu}(\mathrm{II}) \mathrm{N}_{6}$ complexes: elongations, compressions and the pathways in between, J. Chem. Soc., Dalton Trans. (2006) 1092-1100. DOI:10.1039/b509274d

[4] R. Janes, E.A. Moore, Metal-Ligand Bonding, Royal Society of Chemistry, Cambridge, 2004. DOI:10.1039/9781847559456

[5] K.M. Tawfiq, G.J. Miller, M.J. Al-Jeboori, P.S. Fennell, S.J. Coles, G.J. Tizzard, C. Wilson, J.H. Potgieter, Comparison of the structural motifs and packing arrangements of six novel derivatives and one polymorph of 2-(1-phenyl-1H-1,2,3-triazol-4-yl)pyridine, Acta Cryst. B 70 (2014) 379-389. DOI:10.1107/S2052520614001152

[6] J. Conradie, M.M. Conradie, K.M. Tawfiq, M.J. Al-Jeboori, S.J. Coles C. Wilson, J.H. Potgieter, Synthesis, characterization, experimental and theoretical structure of novel Dichloro(bis $\{2-[1-(4-$ methoxyphenyl)-1H-1,2,3-triazol-4-yl- $\kappa \mathrm{N} 3$ ] pyridine- $\mathrm{\kappa N}\}$ )metal(II) compounds, metal = Mn, Co and Ni, J. Mol. Struct. 1161 C (2018) 89-99. DOI:10.1016/j.molstruc.2018.02.036

[7] J. Conradie, M.M. Conradie, K.M. Tawfiq, M.J. Al-Jeboori, S.J. Coles C. Wilson, J.H. Potgieter, Novel dichloro(bis $\left\{2-\left[1-(4-m e t h y l p h e n y l)-1 \mathrm{H}-1,2,3-\right.\right.$ triazol-4-yl- $\left.\kappa \mathrm{N}^{3}\right]$ pyridine- $\left.\left.\kappa \mathrm{N}\right\}\right) \operatorname{metal}(\mathrm{II})$ coordination compounds of seven transition metals ( $\mathrm{Mn}, \mathrm{Fe}, \mathrm{Co}, \mathrm{Ni}, \mathrm{Cu}, \mathrm{Zn}$ and $\mathrm{Cd}$ ), Polyhedron, 2018, in press.

[8] K.M. Tawfiq, G.J. Miller, M.J. Al-Jeboori, P.S. Fennell, S.J. Coles, G.J. Tizzard, C. Wilson, H. Potgieter, Comparison of the structural motifs and packing arrangements of six novel derivatives and 
one polymorph of 2-(1-phenyl-1H-1,2,3-triazol-4-yl)pyridine, Acta Cryst. B70 (2014) 379-389. DOI:10.1107/S2052520614001152

[9] M. Wolff, L. Munoz, A. François, C. Carrayon, A. Seridi, N. Saffon, C. Picard, B. Machura, E. Benoist, Tricarbonylrhenium compounds from 2-pyridyl-1,2,3-triazole ligands bearing a 4substituted phenyl arm: a combined experimental and theoretical study, J. Chem. Soc., Dalton Trans. 42 (2013) 7019-7031. DOI:10.1039/C3DT33071K

[10] D. Schweinfurth, R. Pattacini, S. Strobel, B. Sarkar, New 1,2,3-triazole ligands through click reactions and their palladium and platinum compounds, J. Chem. Soc., Dalton Trans. (2009) 92919297. DOI:10.1039/B910660J

[11] J.D. Crowley, P.H. Bandeen, L.R. Hanton, A one pot multi-component CuAAC “click” approach to bidentate and tridentate pyridyl-1,2,3-triazole ligands: Synthesis, X-ray structures and copper(II) and silver(I) compounds, Polyhedron 29 (2010) 70-83. DOI:10.1016/j.poly.2009.06.010

[12] K.J. Kilpin, E.L. Gavey, C.J. McAdam, C.B. Anderson, S.J. Lind, C.C. Keep, K.C. Gordon, J.D. Crowley, Palladium(II) Compounds of Readily Functionalized Bidentate 2-Pyridyl-1,2,3-triazole "Click" Ligands: A Synthetic, Structural, Spectroscopic, and Computational Study, Inorg. Chem. 50 (2011) 6334-6346. DOI:10.1021/ic200789b

[13] G.A. Bain, J.F. Berry, Diamagnetic Corrections and Pascal's Constants, J. Chem. Educ. 85 (2008) 532-536. DOI:10.1021/ed085p532

[14] Rigaku Corporation, CrystalClear-SM Expert 2.0 r13 Software for Diffractometer, 2011.

[15] O.V. Dolomanov, L.J. Bourhis, R.J. Gildea, J.A.K. Howard, H. Puschmann, OLEX2: A Complete Structure Solution, Refinement and Analysis Program, J. Appl. Cryst. 42 (2009) 339-341. DOI: $10.1107 / \mathrm{S} 0021889808042726$

[16] G.M. Sheldrick, A short history of SHELX, Acta Cryst. Sect. A 64 (2008) 112-122. DOI:10.1107/S0108767307043930

[17] C.F. Macrae, I.J. Bruno, J.A. Chisholm, P.R. Edgington, P. McCabe, E. Pidcock, L. RodriguezMonge, R. Taylor, J. van de Streek, P.A. Wood, Mercury CSD 2.0 - New Features for the Visualization and Investigation of Crystal Structures, J. Appl. Cryst. 41 (2008) 466-470. DOI: 10.1107/S0021889807067908

[18] M.J. Frisch, G.W. Trucks, H.B. Schlegel, G.E. Scuseria, M.A. Robb, J.R. Cheeseman, G. Scalmani, V. Barone, B. Mennucci, G.A. Petersson, H. Nakatsuji, M. Caricato, X. Li, H.P. Hratchian, A.F. Izmaylov, J. Bloino, G. Zheng, J.L. Sonnenberg, M. Hada, M. Ehara, K. Toyota, R. Fukuda, J. Hasegawa, M. Ishida, T. Nakajima, Y. Honda, O. Kitao, H. Nakai, T. Vreven, J.A. Montgomery (Jr.), J.E. Peralta, F. Ogliaro, M. Bearpark, J.J. Heyd, E. Brothers, K.N. Kudin, V.N. Staroverov, R. Kobayashi, J. Normand, K. Raghavachari, A. Rendell, J.C. Burant, S.S. Iyengar, J. Tomasi, M. Cossi, N. Rega, J.M. Millam, M. Klene, J.E. Knox, J.B. Cross, V. Bakken, C. Adamo, J. Jaramillo, R. Gomperts, R.E. Stratmann, O. Yazyev, A.J. Austin, R. Cammi, C. Pomelli, J.W. Ochterski, R.L. Martin, K. Morokuma, V.G. Zakrzewski, G.A. Voth, P. Salvador, J.J. Dannenberg, S. Dapprich, A.D. Daniels, Ö. Farkas, J.B. Foresman, J.V. Ortiz, J. Cioslowski, D.J. Fox, Gaussian 09, Revision D.01, Gaussian, Inc., Wallingford, CT, 2009.

[19] http://www.chemcraftprog.com/

[20] D. Schweinfurth, C.-Y. Su, S.-C. Wei, P. Braunstein, B. Sarkar, Nickel complexes with 'click'derived pyridyl-triazoles ligands: weak intermolecular interactions and catalytic ethylene oligomerisation, J. Chem. Soc., Dalton Trans. 41 (2012) 12984-12990. DOI:10.1039/C2DT31805A [21] M. Mazik, D. Blaser, R. Boese, The potential of $\mathrm{CH} \cdots \mathrm{N}$ interactions in determining the crystal structures of novel 3,4-disubstituted-5-pyridinyl-isoxazoles, Tetrahedron Lett. 41 (2000) 5827-5831. DOI:10.1016/S0040-4039(00)00906-0

[22] M. Mazik, D. Blaser, R. Boese, Intermolecular $\mathrm{CH} \cdots \mathrm{N} / \mathrm{CH} \cdots \mathrm{O}$ hydrogen bonds in the crystal structures of $\alpha, \beta$-unsaturated ketones carrying a terminal pyridine subunit, Tetrahedron 57 (2001) 5791-5797. DOI:10.1016/S0040-4020(01)00520-8

[23] T. Steiner, The Hydrogen Bond in the Solid State, Angew. Chem. Int. Ed. 41 (2002) 48-76. DOI:10.1002/1521-3773(20020104)41:1<48::AID-ANIE48>3.0.CO;2-U

[24] G.A. Jeffrey, An Introduction to Hydrogen Bonding, Oxford University Press, New York and Oxford (1997). 
[25] Y. Yang, P. Du, J. Yang, W.-Q. Kan, J.-F. Ma, A series of $\mathrm{Cu}(\mathrm{II})$ and $\mathrm{Cd}(\mathrm{II})$ coordination polymers constructed by 3,5-dinitrosalicylic acid and flexible bis(triazole) ligands containing different spacers, Cryst. Eng. Commun. 15 (2013) 4357-4371. DOI:10.1039/C3CE00034F

[26] C. Janiak, A critical account on $\pi-\pi$ stacking in metal complexes with aromatic nitrogencontaining ligands, J. Chem. Soc., Dalton Trans. (2000) 3885-3896. DOI:10.1039/B003010O

[27] D. Urankar, A. Pevec, I. Turel, J. Košmrlj, Pyridyl Conjugated 1,2,3-Triazole is a Versatile Coordination Ability Ligand Enabling Supramolecular Associations, Cryst. Growth Design 10 (2010) 4920-4927. DOI:10.1021/cg100993k

[28] I. Bratsos, D. Urankar, E. Zangrando, P. Genova-Kalou, J. Košmrlj, E. Alessio, I. Turel, 1-(2Picolyl)-substituted 1,2,3-triazole as novel chelating ligand for the preparation of ruthenium complexes with potential anticancer activity, J. Chem. Soc., Dalton Trans. 40 (2011) 5188-5199. DOI:10.1039/c0dt01807d 